\title{
A malária em foto: imagens de campanhas e ações no Brasil da primeira metade do século $\mathrm{XX}$
}

\author{
Malaria in pictures: images from \\ Brazil's Public Health campaigns \\ in the first half of the \\ Twentieth Century
}

Gilberto Hochman

Pesquisador, Casa de Oswaldo Cruz/Fiocruz

hochman@coc.fiocruz.br

Maria Teresa Bandeira de Mello

Pesquisadora visitante Faperj, Casa de Oswaldo Cruz/Fiocruz tete@coc.fiocruz.br

Paulo Roberto Elian dos Santos

Documentalista, Casa de Oswaldo Cruz/Fiocruz elian@coc.fiocruz.br

O artigo apresenta e discute um conjunto de fotografias sobre as ações, técnicas, práticas e campanhas contra a malária em três arquivos pertencentes ao acervo da Casa de Oswaldo Cruz/Fundação Oswaldo Cruz que são exemplares de momentos cruciais e distintos da história da luta contra a malária no Brasil do período de 1918 a 1956: Arquivo Belisário Penna, Arquivo Fundação Rockefeller (série Serviço de Malária do Nordeste) e Arquivo Rostan Soares. Relaciona os registros fotográficos sobre a malária com os contextos histórico-sanitários específicos e os modelos e estratégias de campanhas representados por cada um dos arquivos e sugere relações com a própria história do meio fotográfico no século XX. Considera que as imagens da malária constituem fontes privilegiadas para a construção de uma história visual da doença no país ao longo do século XX e da história da saúde pública no Brasil.

PALAVRAS-CHAVE: malária, impaludismo, fotografia, campanhas sanitárias, saúde pública

The article discusses a set of pictures that illustrate public health activities, practices, and campaigns against malaria in Brazil from 1918 through 1956. Exemplary of certain key moments in this history, the illustrations belong to three archives from the Casa de Oswaldo Cruz/Fundação Oswaldo Cruz collection: Arquivo Belisário Penna, Arquivo Fundação Rockefeller ("Serviço de Malária do Nordeste" series), and Arquivo Rostan Soares. The article links these photographic records to their specific historical-public bealth contexts and to the campaign models and strategies represented by each archive. It also draws relations with the $2 O^{\text {th}}$-century bistory of the photographic medium itself. It is argued that these images of malaria constitute prime sources in constructing a visual history of the disease in $20^{\text {th }}$-century Brazil and of the country's public health history.

KEYWORDS: malaria, paludism, photography, public bealth campaigns, public bealth. 


\section{Malária, fotografia e saúde pública no Brasil}

...é nessa imensa Baixada Fluminense, de terras sempre
úmidas, de árvores sempre verdes ... é por aí além, nessas
regiões privilegiadas pelos dons incomparáveis da natureza,
que o homem definha, a raça se aniquila, a vida é destroçada
e as riquezas incalculáveis do solo perduram inaproveitáveis.

Carlos Chagas (1933)

$\mathrm{E}$ m palestra sobre a luta contra a malária no Brasil, Carlos Chagas, diretor do Instituto Oswaldo Cruz (IOC), cientista reconhecido e reformador da saúde pública, apresentava imagens literárias e discutia questões relativas ao combate dessa enfermidade. Chamava a atenção para as principais áreas onde a malária grassava endêmica: a Amazônia, o vale do rio São Francisco, e a Baixada Fluminense, ampla região localizada nos arredores da capital da república, a cidade do Rio de Janeiro, muito perto das elites políticas e intelectuais do país. Ao mesmo tempo, retomava o contraponto, estabelecido pelo movimento médico-higienista dos anos 1910 e 1920 do qual participara: entre doença e civilização, entre um país rico e uma população doente, entre uma natureza generosa e a impossibilidade de usufruí-la. A malária aparecia como principal entrave para o rompimento dessas antinomias. Como combatê-la? Essas eram algumas das preocupações de Chagas um ano antes de seu falecimento. Nesta palestra indicava a necessidade de campanha antipalúdica concentrar-se no que seria o seu principal alvo — os mosquitos transmissores - e utilizando pesticidas, nessas grandes áreas endêmicas. Parte dos argumentos de Chagas já estavam delineados em seu clássico trabalho de 1906, Profilaxia do impaludismo, no qual destacava o caráter domiciliar do mosquito infectante e discutia as estratégias para combatê-lo.

Carlos Chagas, um dos próceres do sanitarismo brasileiro da Primeira República (1889-1930), ressaltava a necessidade de rever a abordagem dos serviços sanitários brasileiros frente à malária, marcada pela associação entre obras de engenharia, uso de larvicidas, educação sanitária e medicação. No início da década de 1930, a ênfase no combate ao vetor já indicava a influência do que seria conhecido como o enfoque norte-americano de controle da malária sobre a saúde pública brasileira, isto é, foco quase exclusivo sobre os mosquitos. A longa experiência da Comissão Sanitária Internacional da Fundação Rockefeller em ações contra a febre amarela no Brasil e América Latina e as campanhas no próprio território norte-americano constituíam argumentos técnicos e científicos persuasivos, mesmo encontrando a oposição de malariologistas europeus, e a forte resistência nos debates na Comissão de Impaludismo da Liga das Nações (Nájera, 2001). 
As décadas de 1930 e 1940 foram marcadas pelo surgimento de estruturas sanitárias e campanhas dedicadas ao combate à malária, levadas a cabo tanto pelo governo brasileiro, que criou o Serviço Nacional de Malária em 1941, o Serviço Especial de Saúde Pública (Sesp) em 1942, por meio de um convênio com o Instituto de Assuntos Interamericanos (IAIA) do governo norte-americano, como pelos esforços empreendidos pela Fundação Rockefeller no Nordeste na erradicação do mosquito Anopheles gambiae no final da década de 1930, e pela ação dos militares norte-americanos em bases militares na mesma região. Também foram caracterizadas pela introdução de novas técnicas e tecnologias no campo da saúde pública e da malariologia, tais como larvicidas, pesticidas, herbicidas, medicamentos, modelos de organização de campanhas e administração de serviços, e novos conhecimentos sobre a epidemiologia da malária, sobre os mosquitos e sua ecologia, sobre a biologia dos parasitos. Em destaque, o DDT, as campanhas verticalizadas e a cloroquina. Essas mudanças e inovações precedem e compõem as condições institucionais e político-sanitárias da dimensão brasileira da Campanha Global de Erradicação da Malária deslanchada pela Organização Mundial de Saúde (OMS) em 1955.

As questões apresentadas por Chagas são explicitadas exatamente num momento de transição na história do Brasil e dos seus serviços de saúde pública: a ruptura com a chamada república oligárquica e a instauração de um novo regime de caráter autoritário, modernizador e centralizador em 1930, que perdurará até 1945, e a criação, também no ano de 1930, do Ministério da Educação e Saúde Pública. O novo ministério era uma antiga demanda do movimento médico-higienista e sua organização pretendia encerrar um período de fragilidade institucional e timidez geográfica que caracterizava a saúde pública até os anos 1920. O intuito era aumentar sua capacidade organizacional e técnica para agir em todo território nacional. Por outro lado, as novas estruturas da saúde pública foram tributárias do processo de reformas, lento porém contínuo, que estava em curso desde meados dos anos 1910, de expansão dos serviços de saneamento e profilaxia rural, em especial no combate às endemias rurais (malária, doença de Chagas e ancilostomíase), que continha forte ideologia estatista e nacionalista. $\mathrm{O}$ novo governo, liderado por Getúlio Vargas, também compartilhava a concepção de que se construiria o "novo" brasileiro por intermédio de políticas de proteção social Gomes, 1988; Hochman e Fonseca, 1999; Hochman, 2001).

A diferença é que as reformas implantadas pós-1930, com a profusão de novas organizações, novos problemas, novas soluções e novos atores, tornaram infinitamente mais complexo o campo da saúde, inclusive as percepções sobre o seu lugar na política brasileira. A saúde pública, enquanto ideologia de construção nacional na década de 1920, foi partilhada por médicos-higienistas e elites políticas (Castro Santos, 1987; Hochman, 1998; Lima, 1999). Ao final do primeiro período de Vargas 
(1930-45), ela continuava sendo patrimônio dos profissionais do setor, mas deixou de ter prioridade na agenda estatal. No período pós-1945, no qual o país se redemocratizou a saúde pública foi herdeira dos aparatos construídos nos anos Vargas, e sua estrutura centralizadora e verticalizada para implementar campanhas sanitárias seria confrontada com a experiência pluralista e democrática que caracterizou o Brasil de 1945 a 1964. No campo institucional, os marcos foram a criação do Ministério da Saúde, em 1953, e a criação do Departamento Nacional de Endemias Rurais (DNERu), em 1956. Nesse sentido, se políticas públicas, política e ideologia continuam a se entrelaçar no campo da saúde publica, em especial, quando o objetivo, retórico ou real, era a saúde das populações rurais, o período pós-1930 foi marcado profundamente pela institucionalização, profissionalização e burocratização da saúde pública.

A palestra de Chagas, profusa em imagens literárias e proferida em um momento crucial de mudanças sociais, políticas e sanitárias no Brasil, registra contrastes, problemas e lugares geográficos que são significativos para o desenvolvimento deste ensaio sobre as imagens fotográficas da malária em arquivos de indivíduos e instituições que se envolveram em ações e campanhas de combate e controle dessa doença na primeira metade do século XX. Pretendemos acompanhar aspectos importantes dessas ações sanitárias por meio de algumas fotografias pertencentes a três arquivos depositados na Casa de Oswaldo Cruz (COC), selecionados por serem relevantes para uma história, também visual, das ações antimalária: Arquivo Belisário Penna, Arquivo Fundação Rockefeller (série Serviço de Malária do Nordeste) e Arquivo Rostan Soares.

É evidente que cada conjunto está marcado pela lógica da ação pública, e privada, dos personagens e das instituições que os produziram e colecionaram e não esgotam as possibilidades de investigação sobre o tema. Porém, consideramos plausível indicar que deles podemos extrair um quadro preliminar de imagens significativas no período que se inicia com os serviços de profilaxia rural (1918-22), dirigidos por Belisário Penna, e se estende às ações do Serviço Nacional de Malária (1941-56), no qual trabalhou Rostan Soares, passando pela campanha contra o mosquito Anopheles gambiae, empreendida pela Fundação Rockefeller no comando do Serviço de Malária do Nordeste (SMN), entre 1939 e 1941. A constatação da profusão de fotografias sobre essa temática nesses arquivos já é, por si mesma, uma questão que instiga os pesquisadores, e foi a motivação inicial desse trabalho. As imagens também se referem em grande medida à geografia da malária indicada por Chagas - o estado do Rio de Janeiro, a região Nordeste e a Amazônia brasileira - e destacam-se claramente nos conjuntos fotográficos imagens de obras de engenharia sanitária (nos arquivos de Penna e Soares), da utilização de larvicidas e pesticidas (na série SMN) e da fabricação e distribuição de sal cloroquinado (no arquivo de 
Soares), o que sugere que a incidência dessas ações nos registros fotográficos esteja de algum modo relacionada a sua importância como estratégia em cada um dos contextos representados pelos três arquivos escolhidos.

O nosso objetivo é destacar a representação, no conjunto de imagens de cada um dos arquivos, das principais estratégias, tecnologias e técnicas utilizadas no combate à malária. A intenção é indicar alguns dos complexos aspectos do envolvimento do Estado brasileiro e de seus serviços com o tema da malária a partir de uma seleção de imagens significativas dos acervos selecionados. Fotografias que ilustram as práticas e técnicas predominantes em um dado contexto político e sanitário, e que são representações visuais da enfermidade e do enfermo desafiam-nos a uma reflexão, ainda preliminar, sobre o "ânimo" pelo registro fotográfico que marca a saúde pública brasileira e latino-americana, sobre as técnicas fotográficas e estilos utilizados, sobre as possíveis intenções de fotógrafos, instituições e personagens, temas que só há pouco começam a ser tomados como objeto central, apesar da historicamente íntima e duradoura relação entre imagem e medicina. ${ }^{1}$

Apesar de sua importância médica, epidemiológica e política, a história da malária no Brasil não tem sido objeto da atenção sistemática dos pesquisadores, nem as fontes foram de todo exploradas. Em geral, esta história é abordada a partir de campanhas específicas e circunscritas geograficamente, como a do gambiae a da malária-bromélia no sul do Brasil entre 1943 e 1950 (Gadelha, 1994; Gadelha e Packard, 1994) ou das ações dos norte-americanos em suas bases no nordeste brasileiro (Campos, 1998-99). Um outro conjunto de trabalhos faz este empreendimento a partir de políticas estaduais de controle singulares, como a de São Paulo (Barata, 1998; Matos, 2000) ou a partir de políticas e instituições que tinham objetivos mais amplos, como os serviços de profilaxia rural, o Departamento Nacional de Saúde Pública, o Ministério da Educação e Saúde e os Serviços Especiais de Saúde Pública (Campos, 2000; Castro Santos, 1987; Hochman, 2001, 1998; Labra, 1985 e Nunez, 1988). Esses autores, em geral, abordam o tema da malária como parte do processo de constituição do Estado no Brasil, de institucionalização da saúde pública, do debate sobre identidade nacional e os entraves impostos pelas endemias, das relações do Brasil com organizações intergovernamentais e de outros países no campo científico e sanitário.

\footnotetext{
${ }^{1}$ Ainda carecemos de trabalhos analíticos sobre história e fotografia na e da saúde pública no Brasil. A seção Imagens de História, Ciências, Saúde - Manguinhos tem contribuído para o desenvolvimento da pesquisa nesse campo. Os artigos de Cueto (1998) e Lacerda (2002) são importantes empreendimentos nessa direção, assim como a dissertação de Thielen (1992), assim os livros de Stepan (2001) e de Vasconcellos (1995). Os comentários de Stepan (1994) ao álbum forográfico A ciência a caminho da roça (Casa de Oswaldo Cruz, 1991) fornecem importantes indicações sobre o trabalho histórico com imagens. Em livro coordenado por Benchimol (2001, pp. 443-7) sobre a história da vacina contra a febre amarela, Aline Lacerda também discute as fontes visuais que constituem essa história.
} 
Parte considerável das reflexões de caráter histórico, que ao mesmo tempo se constituem como fontes secundárias, provêm das memórias — textos, homenagens, entrevistas e livros — daqueles que de algum modo participaram das instituições, políticas e campanhas de combate à malária. ${ }^{2}$

A constituição de uma história visual da malária no Brasil permite o reconhecimento das características e peculiaridades embutidas em modelos diferenciados de campanhas ao longo dessa história, aos quais correspondem estágios específicos no desenvolvimento das políticas e dos saberes relativos à doença. A utilização de fotografias como fontes históricas privilegiadas visa também a um entendimento mais estreito das relações entre esse tipo de medium e a história da medicina e da saúde pública.

É interessante observar que a fotografia, desde seus primórdios, foi incorporada às práticas médicas e científicas em geral como um instrumento preciso e absoluto de observação. Curiosamente, sua inserção inicial na medicina se deu pelo estudo das doenças mentais a partir da segunda metade do século XIX, com a realização de uma série de experimentos fotográficos com pacientes de hospitais e asilos da França e da Inglaterra (Frizot, 1998). Acreditava-se que a imagem fotográfica, dotada de um valor de síntese e de revelação únicos, poderia mostrar, através da fisionomia dos doentes, detalhes de sintomas físicos ou neurológicos que o olho nu muitas vezes não poderia captar imediatamente.

O ingresso oficial da fotografia no campo da medicina se deu com a criação, em 1878, do serviço fotográfico do Salpêtrière, em Paris, por Jean Martin Charcot. Albert Londe (1987), diretor do serviço durante muitos anos, em uma obra intitulada Laphotographie médicale, publicada em 1893, enumera as contribuições da fotografia para a medicina: registro de estados transitórios; autópsias; acompanhamento da evolução das doenças e dos tratamentos etc. Além disso, destaca a possibilidade do estabelecimento de tipologias das doenças a partir da criação de séries de retratos de doentes apresentando sintomas específicos para auxiliar os diagnósticos.

Para se entender melhor a incorporação da fotografia pela medicina, Sander Gilman (1995) chamou a atenção para a conjuntura existente no próprio campo do saber médico e científico na segunda metade do século XIX e início do XX: o surgimento de duas novas disciplinas acadêmicas, a saber, a psiquiatria e a história da medicina. De acordo com sua análise, o emergente campo da psiquiatria precisava encontrar uma epistemologia visual própria, uma genealogia para a nova ciência, paralela àquela existente para as emergentes ciências biomédicas

\footnotetext{
2 As entrevistas compõem o acervo de depoimentos orais da Casa de Oswaldo Cruz; Deane (1985) e Soper e Wilson (1945) são alguns exemplos dessa perspectiva memorialística ou de narrativa de experiências profissionais.
} 
(microscopia, radiologia, entre outras), dominadas pela imagem visual. Dessa forma, a psiquiatria acadêmica do século XIX buscava sua legitimação através da fotografia, retomando uma antiga tradição de representação fisionômica da doença mental. Por sua vez, no mesmo período, o médico e também estudioso da história, Karl Sudhoff, criava a disciplina acadêmica de história da medicina em Leipzig, Alemanha. Bastante familiarizado com o novo medium, utilizou a fotografia em seus trabalhos e defendeu seu uso para o ensino da história da medicina, uma vez que a considerava um processo fotoquímico mecânico capaz de dotar a disciplina de um escopo objetivo (idem, ibidem, p. 24).

Os impactos da fotografia na medicina e nas ciências integraram um processo mais amplo de constituição de uma nova sociedade que emergiu na passagem do século XIX para o XX. A fotografia surgiu no bojo de uma multiplicidade de invenções e inovações técnicas ocorridas nesse período intrinsecamente relacionadas ao desenvolvimento industrial e capitalista, e à construção de um novo tipo de conhecimento. A imagem fotográfica deve ser considerada como uma nova forma de comunicação, fruto de um determinado momento histórico e como um elemento fundamental para a construção da modernidade que conforma uma forma de visualidade própria de seu tempo e altera as práticas e tecnologias tradicionais (Wells, 1997; Mello, 1998). Ao longo do século $\mathrm{XX}$, acompanhando o processo de desenvolvimento tecnológico dos mecanismos e processos técnicos da fotografia, novos usos e funções lhe foram atribuídos pelas práticas médicas, pelo poder público e pelos centros e instituições de pesquisa e ensino. Ela passou a ser utilizada como registro e testemunho das ações desses agentes no combate a diversas doenças e problemas sanitários e também como um elemento importante na educação da população.

Este trabalho não pretende preencher as lacunas e questões sobre fontes visuais e/ou a história das campanhas contra a malária no Brasil, mas levantar questões e indicar caminhos de pesquisa que possam amalgamar enfermidades, saúde pública e fotografia. Na seqüência deste ensaio, abordaremos as imagens mais significativas das ações e das campanhas antimalária no Brasil da primeira metade do século XX em cada um dos três arquivos selecionados e faremos considerações gerais sobre as relações entre fotografia e história da malária e da saúde pública.

\section{Arquivo Belisário Penna: postos de profilaxia, obras e enfermos}

Campanhas contra endemias rurais, e contra a malária em particular, são elementos constitutivos da saúde pública no Brasil. Desde o início do século XX, inúmeras ações que incluíam investigação, tratamento e profilaxia do impaludismo foram executadas pelo governo federal e por alguns estados da federação. Uma tradição de pesquisa sobre a malária e demais endemias se constituiu no eixo Rio-São Paulo, em especial no IOC a partir dos trabalhos de cientistas como Carlos Chagas, 
Adolfo Lutz e Arthur Neiva. Entre meados da década de 1910 e meados da de 1920, no rastro do movimento político pelo saneamento rural, a malária juntamente com a ancilostomíase e a doença de Chagas adquiriram status de "trindade maldita", entrave à civilização, ou dos principais males que tornavam o Brasil, nas palavras do médico e professor Miguel Pereira em 1916, "um imenso hospital" (Hochman, 1998; Lima e Hochman, 1996).

A instalação, com poucos recursos públicos e filantrópicos, de alguns postos de profilaxia e combate à malária e à ancilostomíase na periferia do Distrito Federal na década de 1910 era considerada parte dos objetivos e estratégias da campanha para combater as endemias, educar a população e chamar a atenção da opinião pública. Uma visita ao posto de profilaxia rural dirigido pelo médico Belisário Penna, localizado na Penha, subúrbio da capital, a cidade do Rio de Janeiro, em abril de 1918, teria sensibilizado o presidente da República, Wenceslau Brás, levandoo a promover ações concretas de combate às endemias rurais, ao verificar, segundo comentários de alguns médicos, "a verdade cruel da ... situação mórbida, às portas da capital do país" (Fraga, 1926, p. 528) e "formar uma pálida idéia da calamidade devida às endemias rurais" (Fontenelle, 1922, p. 52). Esta visita resultara da expressiva repercussão da campanha pelo saneamento na imprensa, em fóruns científicos, de classe e profissionais e nos debates no Congresso Nacional e em várias assembléias estaduais (Britto, 1995; Hochman, 1998, capítulos 2 e 3).

Criada em 1918 e liderada por Belisário Penna, a Liga Pró-Saneamento do Brasil tinha como objetivo principal a criação de uma agência pública de âmbito federal que uniformizasse os serviços, realizasse e coordenasse ações de saúde em todo território nacional e superasse os limites constitucionais impostos à ação da União, restrita na área de saúde pública ao Distrito Federal e aos portos. A proposta de centralização dos serviços sanitários era um desafio à ordem política vigente e deveria ser viabilizada pela criação de um Ministério da Saúde Pública. O instrumento legal que viabilizaria essa ação seria um código sanitário válido em todo país e executado pela autoridade sanitária federal, o que não eliminaria, todavia, a necessidade de os estados e municípios criarem os seus próprios serviços sanitários. A autonomia dos serviços federais, que deveriam ser exclusivamente técnicos, seria a garantia da prevalência da ciência contra os interesses políticos, alvo das críticas do movimento (Castro Santos, 1987; Hochman, 1998; Lima e Britto, 1996).

Como resultado de intensa campanha política, o Serviço de Profilaxia Rural do Distrito Federal foi criado no governo Wencesláu Brás, em maio de 1918, inicialmente subordinado à Inspetoria de Profilaxia da Diretoria Geral de Saúde Pública (DGSP), órgão federal responsável pela saúde da capital federal e dos portos e vinculado ao Ministério da Justiça e Negócios Interiores (MJNI). Os primeiros postos criados, em número de dez, visavam ao atendimento de toda a área rural do Distrito Federal, com uma população de cerca de 350 mil habitantes. 
Foram instalados nas seguintes localidades: Gávea, Campo Grande, Jacarepaguá, Madureira, Pilares, Penha, Bangu, Guaratiba, Santa Cruz e Ilha do Governador. No campo da luta antipalúdica, o governo federal também criava o Serviço de Medicamentos Oficiais, por intermédio do qual compraria a quinina e, através do IOC, fabricaria comprimidos que seriam vendidos ou distribuídos pelos serviços de profilaxia rural.

De acordo com o histórico do Serviço de Profilaxia Rural no Distrito Federal, elaborado por Belisário Penna em 1920,

o serviço a princípio era o de ambulatório nos postos para tratamento de verminóticos e impaludados, além de assistência geral aos pobres para outras doenças, o de propaganda e educação higiênica, pela palavra escrita e falada, o de vacinação e revacinação contra a varíola, o de laboratório para pesquisas de vermes, para exames de sangue, ... etc. Mais tarde iniciou-se o serviço sistemático para colheita de material para exame e tratamento a domicílio das pessoas encontradas infectadas de vermes. $^{3}$

Em geral, esses postos contavam com médicos, inspetores sanitários da DGSP, um microscopista, dois médicos ou acadêmicos de medicina, um escriturário, guardas sanitários em número variável, serventes, além de uma turma de trabalhadores para serviços de valas e sarjetas. No entanto, segundo Penna, os postos não se limitavam ao tratamento dos doentes de verminoses e de impaludismo,

mas dão assistência geral a todos os que o procuram, fornecem medicação aos pobres para todas as doenças, praticando operações de pequena cirurgia e fazendo curativos de úlceras e outros. Além disso, realizam trabalhos de hidrografia sanitária, tais como drenagem e aterramento de pântanos, limpeza, abertura de valas, limpeza e retificação de rios etc., e promovem medidas de saneamento geral, tais como a construção de fossas ..., de poços higiênicos, e aterramentos dos defeituosos ou imprestáveis, destruição de plantas que se possam constituir focos de procriação de culicídios. ${ }^{4}$

O impacto devastador da gripe espanhola em fins do ano de 1918 e o aumento do temor do retorno da febre amarela aos portos nacionais somaram-se ao diagnóstico de uma população do interior

\footnotetext{
3 Serviço de Prophiylaxia Rural no Districto Federal e zonas limitrophes do estado do Rio, desde a sua fundação, em junho de 1918 a 31 de outubro de 1920'. Rio de Janeiro, 1920, p. 1. BP/PI/TP/19202040-4. Arquivo Belisário Penna. Departamento de Arquivo e Documentação/ Casa de Oswaldo Cruz/Fundação Oswaldo Cruz.

${ }^{4}$ Relatório apresentado por Belisário Penna ao presidente do estado do Rio de Janeiro, Raul Veiga, sobre os serviços realizados no estado durante o segundo semestre de 1919 e o primeiro semestre de 1920'. Rio de Janeiro, 15 de julho de 1920. BP/PI/TP/19200715. Arquivo Belisário Penna. Departamento de Arquivo e Documentação/Casa de Oswaldo Cruz/Fiocruz.
} 
abandonada e doente e à atuação política da campanha pelo saneamento do Brasil, possibilitando as primeiras reformas dos serviços federais de saúde iniciadas com a criação do Serviço de Profilaxia Rural (decreto de abril de 1919), subordinado diretamente ao MJNI e não mais à DGSP. Nesse novo formato institucional, os estados poderiam receber recursos humanos, técnicos e financeiros por meio de acordos voluntários que transferiam aos serviços federais a responsabilidade direta no combate às endemias rurais. Com isso a profilaxia rural teve sua área de atuação consideravelmente ampliada. Esse foi o mecanismo que, sem caracterizar uma violação da autonomia estadual consagrada pela Constituição Federal de 1891, permitiu a ampliação da presença federal no campo da saúde ao longo da década de 1920, uma presença desejada tanto pelo movimento sanitarista quanto pela maioria dos estados que não tinham recursos para promover políticas sanitárias (Hochman, 1998).

Em dezembro de 1919, após intenso debate político motivado por uma mensagem do presidente da República Epitácio Pessoa, ao Congresso Nacional propondo reformas na saúde pública, o legislativo federal aprovou no penúltimo dia do ano a criação do Departamento Nacional de Saúde Pública (DNSP). Esse novo departamento inaugurava uma nova etapa no desenvolvimento de políticas de saúde pública e de saneamento no Brasil e significava a ampliação das atribuições do governo federal no campo da saúde pública, inclusive com a formulação de um extenso Código Sanitário. O seu primeiro diretor foi justamente Carlos Chagas, entre 1919 e 1926, que acumulou essa função com a direção do IOC. A profilaxia rural foi incluída no DNSP através da Diretoria de Saneamento e Profilaxia Rural (DSPR) que, sob direção inicial de Belisário Penna, foi o serviço de saúde de maior impacto, em especial, no que diz respeito à presença do governo federal nos estados pelos mecanismos de acordos e convênios.

Já em 1922, estavam em funcionamento 88 postos sanitários rurais, em 15 estados e no Distrito Federal, sendo alguns itinerantes nos estados do Amazonas e do Pará, visando atender populações ribeirinhas. Havia mais 16 postos-sede dos serviços nas capitais dos estados e 33 subpostos. Além dos postos federais, havia 58 postos de profilaxia da ancilostomíase e verminoses, em cooperação com a Fundação Rockefeller, em 56 municípios de 11 estados mais o DF (Faria, 1995 e 1994; Hochman, 1998, cap. IV). Note-se que dois estados, Rio Grande do Sul e São Paulo, que não fizeram acordos com a DSPR, fizeram-no com a Fundação Rockefeller. Além de manter quatro postos para o combate à malária, no estado do Rio de Janeiro, a Rockefeller no Brasil auxiliava o estabelecimento de serviços permanentes de higiene municipal, em Minas Gerais e São Paulo. Iniciadas em estados com mais recursos e limitadas à profilaxia da ancilostomíase, essas ações foram expandindo-se para os estados do Norte e Nordeste e para áreas de ensino, pesquisa, profilaxia da 
malária e da febre amarela, as atividades da Fundação Rockefeller acompanharam a interiorização e a diversificação do próprio Estado brasileiro no campo da saúde pública (Faria, 1995 e 1994; Labra, 1985; Hochman, 1998). Uma infra-estrutura nacional de saúde pública insinuava-se lentamente a partir dos acordos para o saneamento rural, começando a preencher os espaços vazios de autoridade e repletos de doenças.

A característica principal das campanhas de profilaxia rural nesse período foi seu forte componente ideológico, leia-se a associação entre nacionalismo, processo civilizador e saúde pública. Do ponto de vista médico-sanitário, o problema das endemias rurais certamente não foi superado, mas as estruturas organizacionais e profissionais que se formaram com as ações de profilaxia e saneamento rural constituiram o processo de formação da autoridade pública no Brasil e legaram ao período posterior as bases para uma política nacional de saúde.

Os postos do Serviço de Profilaxia Rural, criados inicialmente na periferia do Distrito Federal e no estado do Rio de Janeiro e posteriormente disseminados para outras regiões do país, constituem o modelo de ação do governo federal no combate às endemias rurais, especialmente a malária, implementado no final da década de 1910. As fotografias pertencentes ao arquivo pessoal de Belisário Penna, depositado no Departamento de Arquivo e Documentação da COC, são fontes visuais privilegiadas para a compreensão e análise desse modelo. ${ }^{5}$

As imagens da malária existentes no arquivo Belisário Penna encontram-se distribuídas pelos 23 dossiês geográficos da Série Vida Profissional e Política, que abrangem todas as regiões do território nacional. Deste conjunto, destaca-se o dossiê correspondente ao estado do Rio de Janeiro, e à chamada Baixada Fluminense, incluindo aproximadamente 750 fotografias referentes à atuação dos postos de profilaxia rural em localidades tais como Jacarepaguá, Guaratiba, São João de Meriti, Penha, Honório Gurgel, Campo Grande, Santa Cruz, Anchieta, Nilópolis. Em sua maioria, as imagens registram as obras de hidrografia realizadas com o objetivo de combater a fase larvária do mosquito transmissor da malária: dragagem e aterro de pântanos e lagoas; abertura de valas e canais para escoamento de água de áreas pantanosas; desobstrução, regularização e canalização de cursos de rios, e remoção de tudo que contribuisse para o armazenamento de água e que pudesse se constituir como foco do vetor. Essa incidência

\footnotetext{
${ }^{5}$ Composto de cerca de 1.800 imagens, o arquivo fotográfico de Belisário Penna permite o acompanhamento da trajetória política e profissional do sanitarista bem como aspectos de sua vida pessoal e familiar. Organizado em duas séries temáticas, Vida Pessoal e Vida Profissional e Política, inclui imagens das expedições científicas realizadas por Penna ao interior do país, sua atuação no combate às doenças endêmicas brasileiras, a participação na Liga Pró-Saneamento do Brasil, bem como sua gestão à frente do Ministério da Educação e Saúde. Sobre o próprio Belisário Penna ver, "fotobiografia" publicada por Thielen e Santos (2002).
} 
das imagens de obras de engenharia sanitária parece confirmar que essas ações foram a tônica da luta antianofelínica no período, e mesmo até a década de 1940, e sugere que, dado o seu caráter dispendioso e a necessidade de orientação técnica, em especial a drenagem, eram realizadas em áreas populosas, de grande valor econômico, ou estratégicas, tais como as da capital federal e nas áreas que a circundavam.

Encontra-se também amplamente documentado o serviço de atendimento aos pacientes, em especial as fachadas dos postos e suas instalações, e fotografias de impaludados e de pacientes em tratamento. Surpreendentemente, não se encontram registros da quinina, seja, do fabrico, guarda ou medicação com o principal recurso terapêutico contra a malária, e amplamente utilizado nos postos de profilaxia. São freqüentes os registros das conferências e palestras sobre higiene e educação sanitária realizadas pelos médicos nas sedes dos postos e subpostos ou em escolas das áreas rurais. Um outro aspecto que chama a atenção nesse conjunto de fotografias é a grande incidência de imagens de inaugurações de novas sedes de postos, de festas cívicas e religiosas neles realizadas, bem como de visitas de políticos e autoridades, com amplo destaque para Belisário Penna como figura central nas imagens.

\section{Serviço de Malária do Nordeste: eliminado larvas e mosquitos}

A campanha contra o Anopheles gambiae no Nordeste brasileiro, no final da década de 1930, pode ser considerada como um momento fundamental na história da institucionalização do combate à malária no país, uma vez que originou o primeiro serviço especificamente constituído com essa finalidade: o Serviço de Malária do Nordeste. Também diz respeito à longa relação entre o Estado brasileiro e a Fundação Rockefeller, que já estava presente no país desde a década de 1910, e atuava durante a década de 1930 no Serviço de Febre Amarela, através de contratos com o governo brasileiro, sob o comando de Fred Soper e Sérvulo Lima (Williams, 1994). A experiência brasileira de erradicação desse vetor também marcou a história da malária ao introduzir na agenda sanitária internacional o debate sobre as possibilidades de erradicação da malária em uma perspectiva global. ${ }^{6}$

Em março de 1930, Raymond C. Shannon, entomologista do Serviço de Febre Amarela, vinculado à Comissão Sanitária Internacional da Fundação Rockefeller, descobriu a larva de um mosquito Anopheles gambiae em Natal, capital do Rio Grande do Norte. Seria a primeira vez que se encontrava no hemisfério ocidental esse vetor da malária,

\footnotetext{
${ }^{6}$ As informações sobre esta campanha estão baseadas em Benchimol (2001, pp.168-73; Deane (1985); Gadelha e Packard (1994); Nunez (1988); Soper e Wilson (1945) e Soper (1977).
} 
originário da África tropical (Gadelha, 1995, p. 6). Pouco depois, verificaram-se os primeiros surtos de malária em Natal, controlados com a utilização dos métodos tradicionais de combate aos criadouros dos mosquitos: drenagens, aterros e uso de querosene em poças d’água. Os trabalhos de combate ao mosquito transmissor da malária nessa ocasião foram organizados pelo Serviço de Febre Amarela e transferidos posteriormente ao Departamento de Saúde do Estado do Rio Grande do Norte. No decorrer dos anos seguintes, o gambiae alastrou-se em direção ao Norte, subindo pela costa, sem provocar grandes surtos epidêmicos, "até que, em 1938, causou, no vale do Jaguaribe, no Ceará, talvez a maior epidemia de malária já ocorrida em nosso continente" (Deane, 1985, p. 90). A rapidez na propagação do mosquito pela região e as proporções que a epidemia tomara fizeram com que fosse criado, em 5 de agosto de 1938, o Serviço de Obras contra a Malária. Ainda nesse ano, a Fundação Rockefeller iniciou uma investigação sobre as condições sanitárias das regiões ameaçadas pelo gambiae como subsídio para a organização de uma campanha de erradicação do vetor.

Finalmente, em janeiro de 1939, a partir de um convênio de cooperação firmado entre o Ministério da Educação e Saúde e a Divisão Internacional da Fundação Rockefeller, foi criado o Serviço de Malária do Nordeste (SMNE), destinado exclusivamente a combater o Anopheles gambiae naquela região do país. Como diretor do SMNE foi designado Frederic L. Soper, representante da Fundação Rockefeller no Brasil.

A cidade de Fortaleza - centro de vias aéreas, marítimas e terrestres em comunicação com a área infestada pelo gambiae foi escolhida para sede do Serviço. As regiões trabalhadas foram divididas em cinco divisões no estado do Ceará, e duas no estado do Rio Grande do Norte. Cada uma tinha sua sede na cidade da divisão que mais facilidade oferecia para comunicação com todos os pontos da região sob sua responsabilidade. O Laboratório Central foi instalado em Aracati (CE), cidade localizada em uma das áreas mais infestadas pelo gambiae (Soper e Wilson, 1945, p. 33). A estrutura administrativa do SMNE foi estabelecida nos moldes da organização do serviço de Febre Amarela, cujos quadros também foram requisitados para a escolha e o treinamento do pessoal do novo Serviço, e chegou a contar com quatro mil funcionários.

A estratégia adotada para a campanha de erradicação do gambiae fundamentou-se no combate ao mosquito nas fases larvária e alada no território infestado e adjacências; no controle da disseminação através do serviço de expurgo de veículos que deixassem a área infestada e na pesquisa sistemática, objetivando a determinação da presença do vetor em novas áreas. Baseada na delimitação espacial e no mapeamento da região infestada a ser saneada, a campanha organizou o território da doença e orientou suas ações de acordo com uma expansão geográfica para o controle da epidemia. A unidade fundamental na estruturação 
do programa foi a "zona", determinada de acordo com o serviço a ser estabelecido: antilarvário, antialado e distribuição de medicamentos. Além da zona, foram determinadas outras três categorias de organização dos serviços que objetivavam facilitar a fiscalização dos mesmos: o distrito, o posto médico e a divisão.

A base da campanha efetuada pelo SMNE contra o gambiae consistiu, inicialmente, na destruição sistemática do mosquito em sua fase aquática, ou seja, no serviço antilarvário. Nesse sentido, as ações voltaram-se para a proteção das coleções d'água expostas ao sol, consideradas, a partir dos estudos realizados, como locais preferenciais da desova do mosquito. O zoneamento da área nesse momento foi determinado levando-se em consideração o número, a extensão e os tipos de coleção d'água bem como a distância que as separava. Em função das características climáticas do Nordeste, o zoneamento era diferente conforme a estação do ano.

Cada zona foi confiada a um guarda do serviço antilarvário que a percorria semanalmente, tratando as coleções d'água, quer apresentassem ou não larvas e, segundo Leônidas Deane (1985, p. 91), entomologista brasileiro que trabalhou na campanha, a área foi dividida e esquadrinhada de tal maneira que "numa certa época se conhecia, não vou dizer todos, mas praticamente todos os criadouros do gambiae". Os focos larvários foram classificados em atuais (com presença de larvas) e potenciais (com condições favoráveis para se tornarem criadouros) e, inicialmente, tratados com drenagem e petrolagem. A partir do segundo semestre de 1939, foi introduzido o uso do verde-paris como larvicida, método que se tornou predominante no ano seguinte juntamente com o aterro de pequenas coleções líquidas. O controle da eficiência do trabalho realizado era feito pelos guardas a partir de rigorosa pesquisa de larvas em todas as coleções d'água. No final de 1941, em função dos excelentes resultados obtidos, a utilização do verde-paris foi gradualmente suspensa nas áreas consideradas livres da presença do mosquito até a total extinção do serviço antilarvário no primeiro semestre de 1941, sendo mantido apenas o serviço de pesquisa de larvas, em ciclo mensal, como medida de vigilância e prevenção contra a reinfestação.

A segunda grande medida de combate ao gambiae na campanha realizada pelo SMNE foi a de expurgo em domicilios e meios de transporte na região infestada para o extermínio do mosquito em sua fase alada. Este serviço foi organizado em fins de 1939, e em janeiro de 1940 já estava em pleno funcionamento em todas as divisões (Soper e Wilson, 1945, p. 35). Toda a área infestada foi novamente demarcada em zonas, abrangendo número de casas que pudessem ser desinsetizadas em uma semana por uma turma de guardas.

O expurgo era efetuado mediante a aspersão do inseticida obtido pela mistura de extrato de piretro e querosene e era diferenciado nas 
zonas rural e urbana. Em zonas rurais, a turma de expurgo utilizava duas bombas manuais com duas pistolas de aspersão, enquanto nas zonas urbanas, empregava-se uma unidade motorizada montada em uma carroça com uma bomba compressora, que fornecia pressão para três ou quatro pistolas simultaneamente. A tarefa de determinar a incidência do gambiae em cada localidade estava a cargo de turmas de captura, que, depois de aspergirem o inseticida, faziam a coleta dos mosquitos mortos, geralmente, utilizando um guardachuva quadrado de pano branco que amparava os mosquitos no momento da aplicação. A periodicidade do trabalho de expurgo era mensal em toda a área infestada, tornando-se, posteriormente, trimestral e semestral. Quando se constatava a ausência completa do gambiae em uma região por mais de três meses, o expurgo rotineiro das casas era suspenso, embora fosse mantido o serviço de captura como medida de vigilância. Esse serviço funcionou até 31 de março de 1942, colhendo 129.956 alados de gambiae em 14.086 casas das 3.448.467 inspecionadas, tendo gasto 449.212 litros de inseticida (Soper e Wilson, 1945, p. 58).

Além do combate ao gambiae adulto nos prédios da zona infestada e das áreas adjacentes, instituiu-se também o expurgo de veículos, aviões e barcos que, saindo do território infestado, poderiam transportar o mosquito para localidades não infestadas. A preocupação principal era proteger a capital do estado do Ceará e, para tal, foi instalado um posto de expurgo de automóveis em Cristais, na estrada que liga o vale do Jaguaribe a Fortaleza.

A campanha contra o gambiae empreendida pelo SMN apresentou resultados marcantes: em um período de dois anos, o mosquito foi eliminado, reduzindo-se drasticamente a incidência de doença e morte por malária na região. Iniciada em 1939 nos estados do Ceará e Rio Grande do Norte, já em 1940, extensas áreas encontravam-se limpas. No fim desse mesmo ano as pesquisas revelaram a ausência de Anopheles gambiae autóctone no Brasil, dando início a um processo gradual de redução e supressão dos trabalhos. Em 30 de junho de 1942, o Serviço de Malária do Nordeste foi extinto definitivamente. Segundo Leônidas Deane (1985, p. 91), o sucesso da luta contra o gambiae deveu-se à disciplina férrea utilizada no serviço e aos estudos sobre os hábitos do vetor que levaram a descobertas importantes, tais como a de que a cepa de Anopheles gambiae introduzida no Brasil era doméstica, fator fundamental para o estabelecimento da aspersão de inseticidas nas moradias como uma das diretrizes principais da campanha.

O conjunto de cerca de quinhentas fotografias existentes no acervo do Departamento de Arquivo e Documentação da COC sobre a campanha de erradicação do gambiae no Nordeste brasileiro integra a série Serviço de Malária do Nordeste do Arquivo da Fundação Rockefeller e permite o acompanhamento das estratégias e ações 
implementadas pelo SMNE nos seus mais variados aspectos, além de revelar características das formas de organização e planejamento da campanha.

Incorporada à rotina dos trabalhos desenvolvidos pelos médicos, pesquisadores e funcionários do serviço, a prática de produção de registros fotográficos gerou imagens que oferecem um rico painel sobre o amplo espectro de atividades realizadas para a erradicação do mosquito transmissor da malária naquela região. Concentrando-se principalmente nos aspectos da campanha desenvolvida no estado do Ceará (297 registros), as fotografias abrangem o período de 1938 a 1943 e encontramse coladas em fichas catalográficas contendo, em geral, as seguintes informações: assunto, local, data de produção da imagem ou do seu recebimento, numeração, nome do autor da imagem ou de quem a encaminhou.

Todas as atividades referentes ao serviço antilarvário estão detalhadamente documentadas no conjunto de fotografias do SNM: pesquisa e demarcação de focos; serviços de coleta d'água; construção de valas para escoamento de lagoas; eliminação de focos com petróleo e com verde-paris; processo de mistura de verde-paris; aterramento de coleções d'água e fiscalização. Observa-se a grande incidência de imagens relacionadas principalmente ao trabalho de pesquisa de focos, contemplando não apenas as atividades realizadas pelos médicos e guardas, como também inúmeros registros focalizando os criadouros levantados, numerados e tratados. A segunda grande diretriz estabelecida para a campanha, o combate ao mosquito na fase alada, também se encontra amplamente coberta pelos registros fotográficos. As imagens concentram-se basicamente nos trabalhos de expurgos domiciliares e no serviço de captura de mosquitos com o guarda-chuva quadrado. Da mesma forma, constam fotografias de expurgos de aviões, barcos e dos trabalhos de inspeção e telagem dos barris d'água de jangadas, realizados pelo Serviço Marítimo.

Além das atividades relacionadas diretamente ao combate ao gambiae, o material contempla aspectos da organização e estruturação da campanha, como os laboratórios, as seções cartográfica e fotográfica e os serviços de pesquisa de dados metereológicos e inquéritos epidemiológicos. Destacam-se as fotografias referentes ao Laboratório Central, instalado em Aracati (CE), que desempenhou um papel fundamental na identificação das características do gambiae que o distinguissem dos outros mosquitos transmissores da região. Além das fachadas e instalações dos escritórios e laboratórios, encontram-se

\footnotetext{
${ }^{7} \mathrm{O}$ arquivo fotográfico da Fundação Rockefeller é constituído de cerca de 15 mil imagens referentes aos trabalhos desenvolvidos por essa instituição na pesquisa e no combate à febre amarela e à malária, no Brasil e na América Latina, nas décadas de 1930 e 1940. Encontra-se organizado nas seguintes séries: Serviço de Febre Amarela; Serviço de Malária do Nordeste; Fotos Aéreas e Exposições do Serviço de Febre Amarela e do Serviço de Malária do Nordeste.
} 
documentados os equipamentos e instrumentos utilizados nas pesquisas: mesas para identificação de alados; microscópio para exame de larvas; classificador de alados; gaiolas de tela para a criação de mosquitos adultos; receptáculos com larvas em evolução; sala telada para a criação de larvas de mosquito etc.

O papel fundamental assumido pela Seção de Cartografia para a estruturação da campanha é revelado pela existência de cerca de setenta fotografias de mapas produzidos para a demarcação dos limites de zonas, distritos e divisões das áreas onde as medidas de combate ao gambiae estavam sendo aplicadas, bem como aqueles contendo dados sobre as áreas infestadas pelo gambiae; as localidades onde foram feitos os inquéritos epidemiológicos; os índices de redução da área infestada; as áreas cobertas pelas turmas de investigação do SNM e a organização do serviço de pesquisa de larvas nos estados do Ceará e do Rio Grande do Norte.

Há poucos registros sobre o terceiro serviço definido como prioritário na organização da campanha: a medicação. Resumem-se basicamente a fotografias de guardas medicadores encarregados da distribuição de quinina e atebrina. A lacuna pode sugerir que, na prática, essa atividade não foi enfatizada da mesma forma que as outras diretrizes de ação. Alguns autores, inclusive, chamam a atenção para o fato de a campanha ter se concentrado exclusivamente na erradicação do mosquito, deixando de lado os cuidados médicos e a dimensão humana e social da epidemia (Gadelha,1995; Medina,1988), sob a responsabilidade dos serviços de saúde locais, quando existiam, os cuidados clínicos. Assim, os registros significativos dessa série dizem respeito à principal estratégia desta campanha: o combate ao mosquito em suas fases larvária e alada, daí resultando todas as ações registradas em fotografia.

\section{Rostan Soares: o Serviço Nacional de Malária e o sal cloroquinado}

Criado em abril de 1941, com a finalidade de organizar e executar o combate à malária, bem como realizar estudos e pesquisas sobre a doença, o Serviço Nacional de Malária (SNM) foi organizado no contexto de uma ampla reforma do Departamento Nacional de Saúde (Hochman e Fonseca, 1999). ${ }^{8}$ Nos primeiros anos de atividade, o SNM teve seu programa de combate à malária centrado no uso de medidas dirigidas contra as fases aquáticas dos transmissores. Entre estas medidas,

\footnotetext{
${ }^{8}$ O SNM foi instituído pelo decreto-Lei 3.171 de 2.4.1941 que reorganizou o Departamento Nacional de Saúde. O mesmo ato estabeleceu, que ficavam incorporados e fundidos ao SNM, o Serviço de Malária da Baixada Fluminense e o Serviço de Malária do Nordeste. Este, contudo, teve organização desvinculada do SNM, enquanto permaneceu sob a administração contratada da Fundação Rockefeller.
} 
destacam-se as obras de drenagem, aterros e aplicações de substâncias larvicidas, como o verde-paris e o petróleo, além de inquéritos e investigações epidemiológicas e entomológicas. No sul, a destruição das bromeliáceas, através da retirada manual e da derrubada de matas foi a forma de combater a transmissão por espécies do subgênero Kerteszia (Gadelha, 1994). Estas atividades estavam a cargo dos serviços de campo, estruturados em circunscrições e distritos ${ }^{9}$. Dirigidos por sanitaristas que coordenavam e supervisionavam os trabalhos de técnicos de laboratório, engenheiros, topógrafos e equipes de trabalhadores, os serviços de campo garantiam a presença do Estado nas regiões mais remotas do país, continuando um processo iniciado pelos serviços sanitários na década de 1910.

O SNM foi instrumento decisivo de intervenção federal no campo da saúde pública e base institucional para os novos experimentos de combate às endemias rurais nos anos 1940, e para a conversão das ações de controle em erradicação em meados dos anos 1950. O SNM, sua estrutura, assim como seus quadros dirigentes, não foram muito afetados com o final do Estado Novo e com a redemocratização do país, e se transformou em principal alicerce das ações sanitárias no interior do Brasil até 1956, quando todos os serviços nacionais foram fundidos no Departamento de Endemias Rurais (DNERu), que foi chefiado inicialmente por aquele que vinha dirigindo o SNM desde os seus primórdios, Mário Pinotti.

No Arquivo Rostan Soares ${ }^{10}$, encontra-se material fotográfico que registra de maneira expressiva as obras de drenagem e aterros em região do estado do Rio de Janeiro, onde o médico sanitarista atuou como chefe do 6o Distrito, com sede em Macaé e área de abragência que reunia ainda os municípios de Casimiro de Abreu, Santa Maria Madalena e Trajano de Morais. Nestas, como em outras localidades do país, as frentes de trabalho do SNM resumiam-se em intensa atividade da polícia de focos, dos serviços de pequena hidrografia sanitária e do emprego de medicação.

\footnotetext{
${ }^{9}$ A estrutura dos serviços de campo, com pequenas alterações, manteve-se praticamente inalterada durante a década de 1940. Em 1944, para efeito de execução dos trabalhos de campo, o território foi dividido em seis circunscrições, compreendendo cada uma um grupo de estados ou setores.

${ }^{10}$ Rostan de Rohan Loureiro Soares (1914-96) nos primeiros anos de sua trajetória profissional, entre 1942 e 1947, atuou como médico sanitarista, exercendo funções de chefia nos serviços de Febre Amarela e Malária. Durante esse período, em 1942, especializouse em malária freqüentando o curso do Departamento Nacional de Saúde. Seu percurso de pesquisador, dedicado aos trabalhos de laboratório, iniciou-se em 1947 quando, a pedido de Mário Pinotti, diretor do SNM, fez estágio na Seção de Protozoologia do Instituto Oswaldo Cruz sob orientação de Júlio Muniz. Nesse período, já acompanhava o processo de criação do Instituto de Malariologia, órgão de pesquisas do Serviço Nacional de Malária, onde chefiaria o Laboratório de Parasitologia. Ver Fundo Rostan Soares: inventário analítico. Departamento de Arquivo e Documentação. Casa de Oswaldo Cruz. Fiocruz, 1998. 74 p.
} 
O relatório do ano de 1943 , relativo ao 6o Distrito é o documento em que encontramos um conjunto de 82 fotografias que, além de revelarem aspectos da cidade de Macaé, registram de forma especial as condições sanitárias encontradas e as obras de saneamento executadas e previstas para o ano seguinte. O relatório contém, portanto, um expressivo "documento fotográfico" produzido a partir do universo de aproximadamente 160 imagens geradas na rotina das tarefas de saneamento através de projetos de pequena e média hidrografia que incluíam drenagens, roçados e aterros. Nesse período pré- DDT, as obras de engenharia sanitária eram as principais ações dos serviços sanitários federais, especialmente na área rural do Distrito Federal e nas cidades com importância econômica estratégica em cada estado. Cerca de $85 \%$ das imagens produzidas neste período focalizam com detalhes todo o "sistema de valas" da região antes e depois das intervenções de saneamento do SNM. Tema constante entre essas fotografias, as obras de hidrografia sanitária tinham no método da drenagem antipalúdica o instrumento para a extinção das coleções d'água que constituiam focos preferenciais de anofelinos.

A compreensão do contexto de produção deste material fotográfico requer o entendimento do processo de organização e funcionamento destes serviços nacionais, instituídos sob a ótica do registro rigoroso de todos os trabalhos cumpridos como fator de ordem técnico-administrativa indispensável ao bom desempenho das campanhas. A fotografia, ao lado do texto, serve não apenas como elemento de informação e prova das ações realizadas, mas também como elemento componente de instrumentos técnicos especializados de normalização. Mas inserem-se, sobretudo, no cumprimento "a disposições regulamentares da diretoria do SNM", isto é, à produção de relatórios mensais e/ou anuais como forma de acompanhamento das ações do serviço em todo país, comandadas pelos médicos sanitaristas, principais agentes na condução da implementação das políticas de saúde do período (Fonseca, 2000).

A necessidade de um órgão de pesquisas e investigações científicas levou, em 1946, à criação do Instituto de Malariologia. Concebido como escola e centro especializado de estudos e pesquisas no terreno da malária, destinado à formação de técnicos e ao aprimoramento dos métodos de trabalho em bases científicas, que pudessem servir de referência para conduzir a experiência nacional, o instituto seria inaugurado em maio de 1949 no município de Duque de Caxias, Rio de Janeiro, no local conhecido como Cidade das Meninas. Neste ambiente institucional, onde Rostan Soares chefiou o Laboratório de Parasitologia entre 1949 e 1955, em estreita cooperação com o Laboratório de Protozoologia do IOC, é que foram iniciadas as pesquisas para obtenção do sal cloroquinado. $\mathrm{O}$ instituto, em seus primeiros anos de atividade, realizou estudos 
ecológicos sobre mosquitos transmissores da malária, além de fabricar o inseticida hexaclorociclohexano (BHC) usado na campanha contra a doença de Chagas e a filariose.

Em seus primeiros anos de atuação, foi possível ao SNM controlar a malária ao longo da faixa litorânea do território, com a aplicação dos inseticidas de ação residual (DDT), a partir de 1945 combinados com novos medicamentos. Essas ações já faziam parte do cardápio do Serviço Nacional de Malária, em particular nas áreas mais endêmicas como o vale do rio São Francisco, a Baixada Fluminense e o litoral sul do país. Introduzido no Brasil já em 1945, o DDT foi utilizado em menor escala, durante o ano de 1947, em campanha na região do rio São Francisco, que abrangia áreas endêmicas de estados nordestinos (Bahia, Alagoas e Sergipe) e de um importante estado do Sudeste, Minas Gerais, áreas de população mais dispersa e predominantemente rural. A dedetização estava sempre associada à distribuição de medicamentos antimaláricos e a obras hidrográficas e ações antilarvárias. Na Amazônia brasileira, as ações estavam desde 1942 sob a responsabilidade do Serviço Especial de Saúde Pública (SESP) e dos seus técnicos norte-americanos. Contudo, a malária ainda existia em certas regiões do país, permanecendo como desafio, desde o início do século, o problema da endêmica zona rural da bacia amazônica, onde vivia uma população espalhada sem pouso fixo ao longo da vasta rede de cursos d'água, muitas vezes de difícil acesso, ocupada em atividades como caça, pesca e extração de borracha, vivendo em condições precárias. Além disso, os hábitos do principal mosquito transmissor na região dificultavam o uso eficiente do DDT em casas e abrigos utilizados por essa população.

Em fins de 1947, o SNM deu início a uma grande campanha de controle da malária no estado do Rio de Janeiro, na chamada Baixada Fluminense, que duraria sessenta dias e incluiria 1.821 localidades em trinta municípios de norte a sul do estado, inclusos todos aqueles territorialmente contíguos à então capital federal. Os inimigos principais eram mosquitos de espécies de comprovada domesticidade, que caracterizavam a transmissão no estado. Esta campanha é considerada a primeira na América Latina que se utilizaria massivamente de dicloro-difenil-tricloroetano (DDT) em domicílios urbanos e periurbanos como principal estratégia de combate à malária em áreas endêmicas. Além dos trabalhos de dedetização, a campanha desenvolvida na Baixada Fluminense baseou-se na assistência medicamentosa aos doentes de malária, a partir da distribuição gratuita da cloroquina, também conhecida como Aralen. Para tal, foi organizada uma ampla rede de Unidades Distribuidoras de Antimaláricos (UDAs) em toda a região, que incluía, além dos postos de saúde e assistência já existentes, escolas públicas e particulares, fazendas, prefeituras municipais, agências de correio e igrejas (Hochman e Mello, 2001). 
A utilização da cloroquina, administrada em dose única, tinha por objetivo a cura clínica imediata do indivíduo, evitando a interrupção de suas atividades, e apresentava uma grande vantagem em relação aos antimaláricos anteriormente conhecidos, que demandavam um prazo maior de tratamento, sob orientação e controle de pessoal especializado. Reduzindo o tratamento a uma dose única, que podia ser ministrada pelas UDAs, dispensando organização de uma estrutura intensiva em pessoal, a cloroquina foi considerada como o antimalárico mais indicado para as grandes campanhas realizadas pelo SNM em fins da década de $1940 .{ }^{11}$

Em 1952, a partir de um método de profilaxia medicamentosa idealizado por Mário Pinotti, diretor do SNM, foram iniciadas as pesquisas experimentais e os trabalhos de campo com vistas ao desenvolvimento de um antimalárico que solucionasse o problema endêmico na Amazônia: surgia o sal cloroquinado ou Método Pinotti, como se tornou conhecido. ${ }^{12}$ Para observação do uso do sal cloroquinado no campo, foram escolhidas três áreas do país: uma zona central do estado do Pará, localidades do litoral do estado do Maranhão e ilhas da costa do Paraná. Estas zonas foram escolhidas por não contarem com população protegida por inseticidas de ação residual e serviços de medicação, apresentando altos índices parasitários.

As pesquisas com doentes hospitalizados e as experiências no Pará, Maranhão e Paraná encontram-se documentadas no Arquivo Rostan Soares através de correspondência, cadernos de laboratório, memórias, relatórios e trabalhos científicos que descrevem o processo de formulação e emprego do sal como antimalárico. ${ }^{13}$ No que se refere às imagens, os primeiros anos das experiências, entre 1952 e 1953, encontram-se documentados através de registros fotográficos que cobrem as observações com doentes hospitalizados e todo o processo em zonas endêmicas que envolvia os inquéritos

\footnotetext{
11 Em junho de 1949, o combate à malária na Amazônia e no vale do Rio Doce, que vinha sendo feito pelo SESP desde 1942 passou para o controle do SNM.

12 Dada a dificuldade de utilização do método clássico da administração periódica de drogas antimaláricas em populações em vastas áreas rurais, o método propugnava a mistura de difosfato de cloroquina (Aralen) com o sal de cozinha, para ser distribuído, por vários meios, às populações das regiões endêmicas, em especial na Amazônia, substituindo o sal comum na sua alimentação diária. Esse método e a estratégia foram publicados na Revista Brasileira de Medicina em Pinotti, 1953).

13 O relato consolidado da experiência encontra-se na Memória inédita apresentada em 1957 por Mário Pinotti, para concorrer a uma vaga de membro titular da Academia Nacional de Medicina, com o título 'O sal de cozinha como veículo de medicamentos antimaláricos: um método brasileiro de profilaxia do impaludismo. Sua importância na erradicação da doença' (ver RS/PI/TT 19572040). Dois anos antes, Rostan Soares, seu principal colaborador e coordenador dos testes físico-químicos de laboratório e experiências de profilaxia com doentes hospitalizados, foi agraciado com o $1^{\circ}$ prêmio Mário Pinotti da Academia de Medicina, pelo trabalho 'Sal cloroquinado, novo método de profilaxia da malária' (ver RS/PI/TP 19552040).
} 
epidemiológicos e a produção, o transporte e a distribuição do antimalárico à população. Das três áreas escolhidas não encontramos registros fotográficos da experiência no Maranhão. Os conjuntos fotográficos referentes às experiências nos estados do Pará e Paraná configuram uma notável síntese dos primeiros anos da experiência. Estes mesmos conjuntos revelam a capacidade de mobilização de recursos e de estrutura operacional de que dispunha o SNM para as pesquisas e, sobretudo, o emprego do método em condições naturais, em zonas endêmicas de diferentes regiões do país. ${ }^{14}$

Dessa forma, o transporte aéreo e o uso combinado de lanchas do próprio serviço com pequenos barcos, a instalação de estruturas de produção do sal e a mobilização de equipes para distribuição do medicamento e realização de inquéritos epidemiológicos são aspectos contemplados que denotam a complexidade do combate à doença em amplas áreas, com população rarefeita e escassez de transportes. Essa gigantesca tarefa de distribuir o sal cloroquinado pelo interior da Amazônia está bem documentada nas fotografias do arquivo de Soares.

No Pará, as equipes do SNM percorreram trechos do rio Capim, entre as vilas de Aningal e Kiandêua, zona escolhida para a experiência, ficando como testemunha a área do rio Guamá. Estes trabalhos foram realizados entre julho de 1952 e maio de 1953, quando o uso do sal foi interrompido. Em 1955 e 1956, foram levantados os índices parasitários e reiniciado o emprego do método. ${ }^{15}$ No Paraná, a escolha recaiu sobre a Ilha do Teixeira, situada na bacia de Paranaguá, que já servira como testemunha para os serviços do DDT. Ao lado desta, aonde seria aplicado o sal cloroquinado, foram selecionadas as ilhas do Camargo e Currais, como novas áreas-testemunha. O Serviço de Sal Cloroquinado foi instalado em outubro de 1952, na Ilha do Teixeira, onde a população de 173 habitantes passou a utilizar o produto na alimentação e na salga do peixe. Localidade que, em 1952, ainda apresentava índice hemoscópico expressivo, provavelmente por não ter sofrido desinfestação em anos anteriores, a Ilha do Teixeira, entre outubro de 1950 e dezembro de 1951, passou por um processo intenso de desinfestação de todas as habitações e medicação por intermédio das UDAs. Em um conjunto de 29 fotografias que revelam aspectos das instalações do Setor Paraná na ilha, da produção do sal cloroquinado no misturador manual e todas as etapas anteriores de preparo da solução concentrada de

\footnotetext{
${ }^{14}$ Incluímos no caderno de imagens que acompanha este ensaio uma fotografia da distribuição do sal cloroquinado na região amazônica pertencente ao Arquivo Aristides Lima Verde, médico-sanitarista dos quadros do Ministério da Saúde.

15 Ainda na região amazônica, foi iniciado, em fevereiro de 1957, o emprego no sal no então Território Federal do Amapá.
} 
difosfato de cloroquina e do sal antimalárico, habitantes e trabalhadores do SNM e a distribuição e transporte em barcos até os locais de moradia, encontra-se um mosaico de todos os elementos da experiência no campo. ${ }^{16}$

Segundo Mário Pinotti, idealizador do método que levou seu nome, o sal cloroquinado tinha mostrado em diferentes regiões do país, inclusive na Amazônia, sua capacidade de interromper a transmissão da malária, tendo indicação para substituir os inseticidas de ação residual em áreas onde a erradicação do vetor não fosse possível, por motivos técnicos ou econômicos (apud Moraes, p. 463). Independentemente da avaliação positiva dos resultados preconizada por seus idealizadores e realizadores, a experiência com o sal cloroquinado na Amazônia estendeu-se até meados da década de 1960. Aliada a outros fatores, a resistência cada vez maior dos plasmódios à cloroquina parece ter inviabilizado a continuidade de sua utilização junto com o sal.

O conjunto de imagens do arquivo Rostan Soares ${ }^{17}$ expressa duas linhas de ação do Serviço Nacional de Malária associadas à própria trajetória do personagem, em dois momentos: antes da introdução do DDT e diante do desafio das dificuldades de sua utilização na Amazônia. A primeira diz respeito à manutenção das obras de engenharia sanitária em áreas urbanas e periurbanas e, a segunda, esforço monumental empreendido pelo SNM na distribuição de sal cloroquinado por vastas áreas rurais, em especial na Amazônia, e os inquéritos associados ao consumo do sal e de sua ação profilática. O resgate visual e histórico do episódio do sal cloroquinado, considerado por muitos nos anos de 1950 e 1960 a grande contribuição brasileira à malariologia, nos remete aos desafios nacionais no controle da malária nos tempos da campanha global de erradicação.

\section{Conclusão}

As imagens da malária existentes no acervo da COC constituem fontes privilegiadas para a construção de uma história da doença no país ao longo do século XX. Proveniente de arquivos e coleções institucionais e pessoais, essa documentação iconográfica encerra registros representativos de algumas das principais ações e campanhas implementadas nesse período e nos coloca algumas indagações que gostaríamos de levantar e sugerir como possibilidades futuras de reflexão e pesquisa.

\footnotetext{
16 Parte deste conjunto de fotografias, consta de dois relatórios do SNM — Setor Paraná, de abril de 1953. Ver Fundo Rostan Soares, RS/DT/SC/19520124, maço 1, pasta 161.

17 O Arquivo Rostan Soares possui cerca de 1.400 documentos fotográficos. Reúne conjuntos documentais que retratam a trajetória profissional e científica de Soares com destaque para as ações e experiências de campo no combate à malária e à esquistossomose no Brasil, entre as décadas de 1940 e 1980.
} 
Em primeiro lugar, apresenta-se a questão da relação entre essas imagens e a história da Fundação Oswaldo Cruz (Fiocruz), uma instituição que surgiu em 1900 como um laboratório destinado à produção de soro e de vacina contra a peste bubônica e se transformou no maior centro de medicina experimental da América Latina (Benchimol, 1990), intrinsecamente ligado à formulação, planejamento e execução de políticas públicas de saúde no Brasil. É de fundamental importância situar o papel desses registros no contexto mais amplo de desenvolvimento das pesquisas e atividades científicas e sua relação com os atores e instituições por elas responsáveis.

Uma vez estabelecidas as relações existentes entre os arquivos e a história da Fiocruz - e, consequentemente, da medicina e da saúde pública no Brasil —, coloca-se a questão da definição do estatuto dos documentos iconográficos sobre a malária dentro desse contexto. Trata-se de identificar e analisar os diversos usos e funções das fotografias ao longo da história da doença no país, levando-se em consideração as características e os contextos específicos de produção, acumulação e circulação dessas imagens.

Uma primeira avaliação do material iconográfico pertencente aos arquivos representados neste trabalho permite a identificação de uma multiplicidade de aspectos envolvendo a produção e a utilização dessa documentação. Inicialmente, destaca-se o fato de que cada um desses conjuntos de fotografias corresponde a estágios diferenciados do desenvolvimento do saber científico sobre a malária ao longo do século XX e é exemplar de diferentes formas e estratégias de combate à doença em contextos históricos específicos.

O grande volume de imagens de obras de engenharia sanitária existentes, por exemplo, no arquivo pessoal de Belisário Penna mostra a ênfase que era dada no início do século XX ao combate à fase larvária do vetor transmissor da malária. Por sua vez, as fotografias referentes à campanha contra o Anopheles gambiae no Nordeste brasileiro, coordenada pela Fundação Rockefeller, no final da década de 1930, revelam a importância que assume nesse momento o emprego de inseticidas como estratégia de ação para a erradicação da doença nos casos de epidemias, mesmo que se mantenha o combate à larva do mosquito. Já os registros do arquivo de Rostan Soares são decorrentes de um momento em que o entusiasmo pelo DDT declinava - fosse pela descoberta da resistência biológica desenvolvida por algumas espécies de anofelinos ao inseticida ou pelo insucesso de algumas campanhas realizadas, especialmente na região Amazônica - e, nos fóruns científicos nacionais e internacionais, se discutia a pertinência de programas baseados no controle ou na erradicação da doença cujas estratégias mesclavam diferentes tipos de ação. 


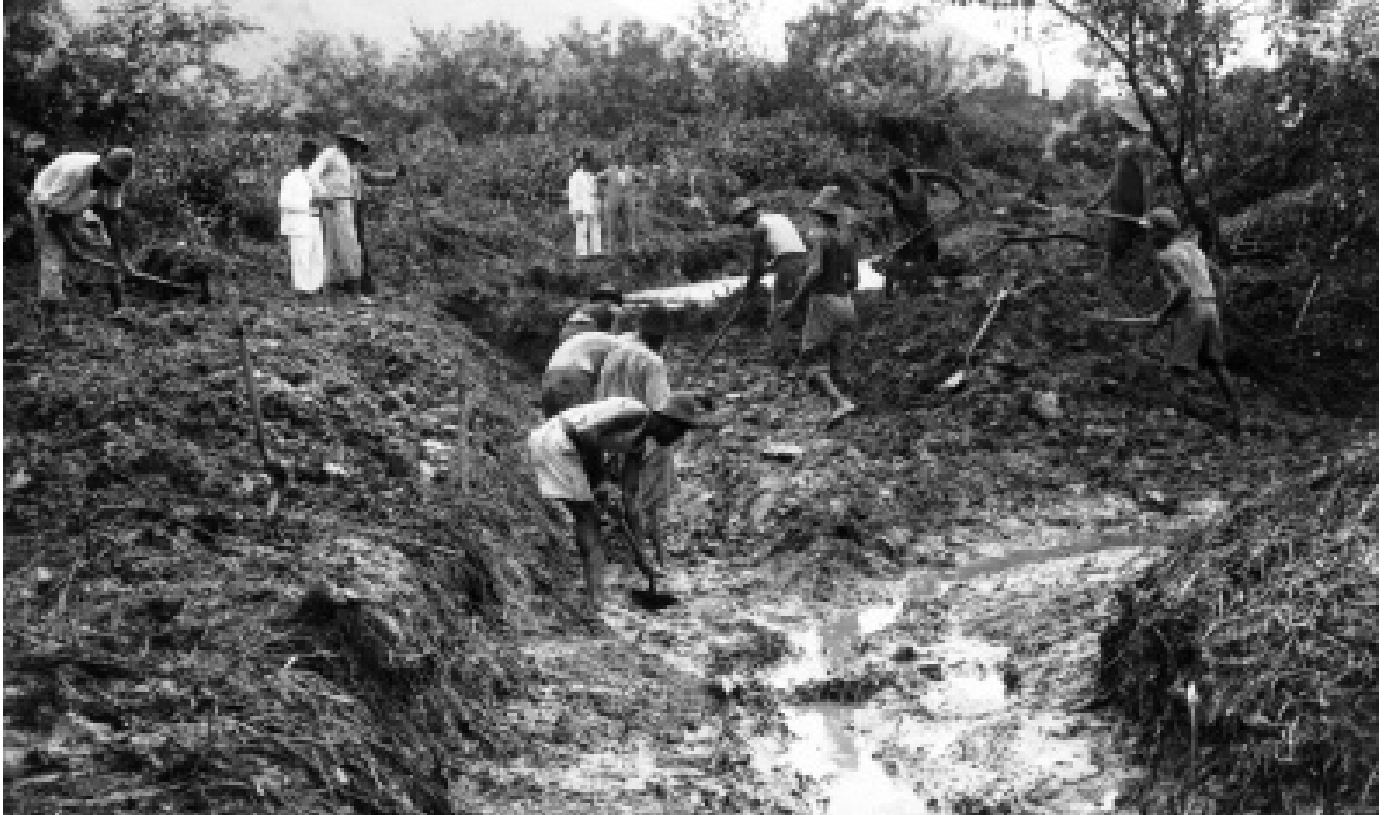

ans.
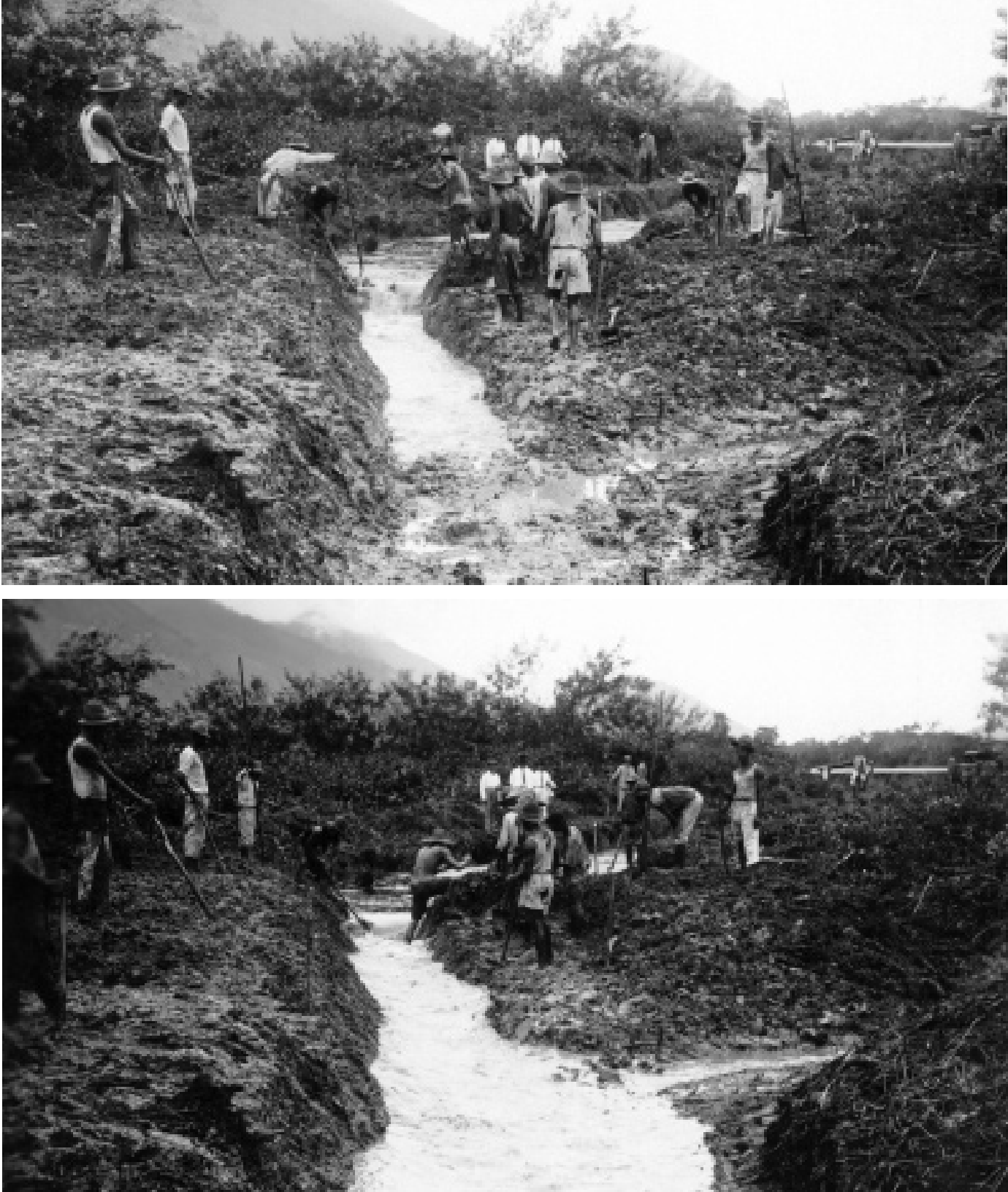

Obras de engenharia sanitária realizadas pelo Serviço de Profilaxia Rural em Campo Grande, Rio de Janeiro. Entre 1918 e 1922.

Arquivo Belisário Penna, Casa de Oswaldo Cruz/ Fiocruz. 


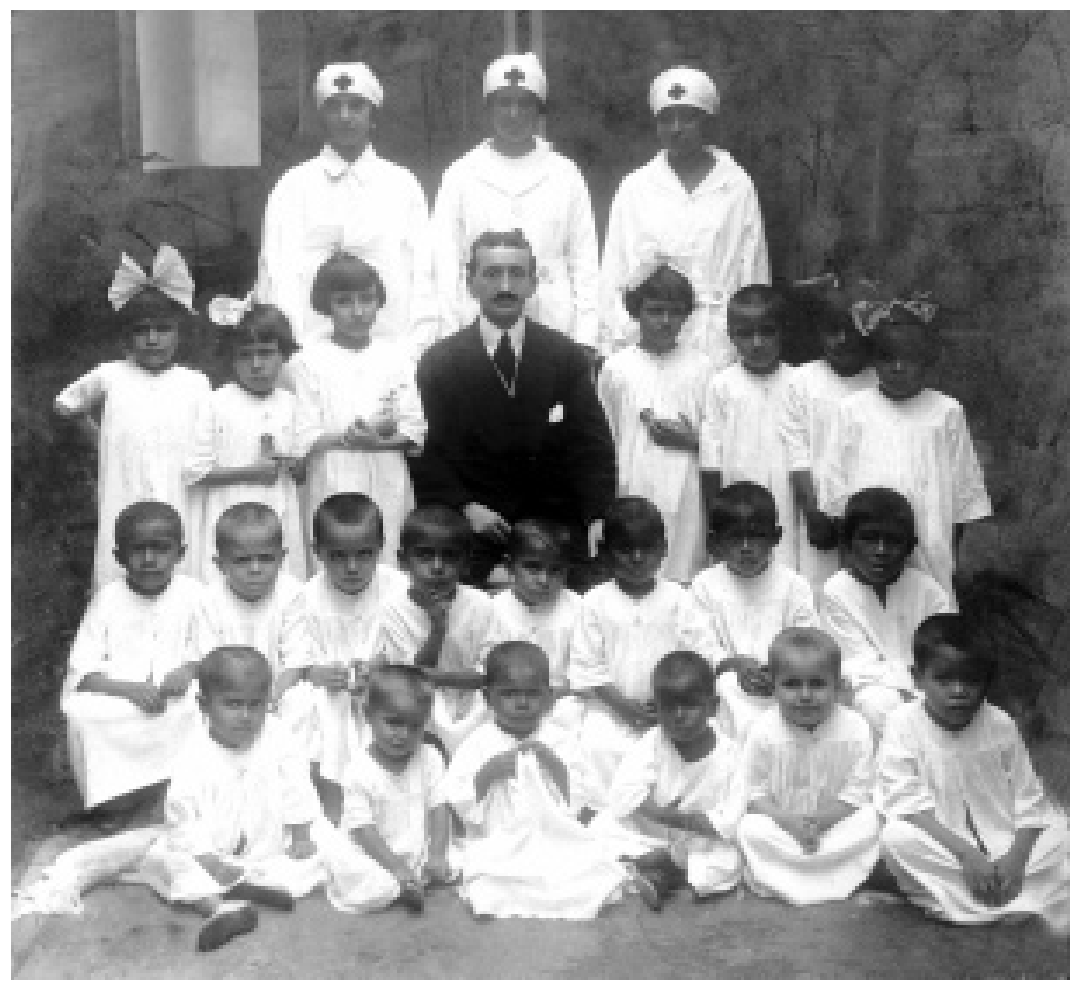

Grupo de crianças medicadas contra a malária no Serviço de Profilaxia Rural do Amazonas. No centro, Samuel Uchôa, diretor do Serviço. Entre 1918 e 1922. Arquivo Belisário Penna, Casa de Oswaldo Cruz/Fiocruz.
Doente de Malária com baço e fígados dilatados. Posto de Profilaxia Rural em Merity, Rio de Janeiro. Entre 1918 e 1922. Arquivo Belisário Penna, Casa de Oswaldo Cruz/Fiocruz

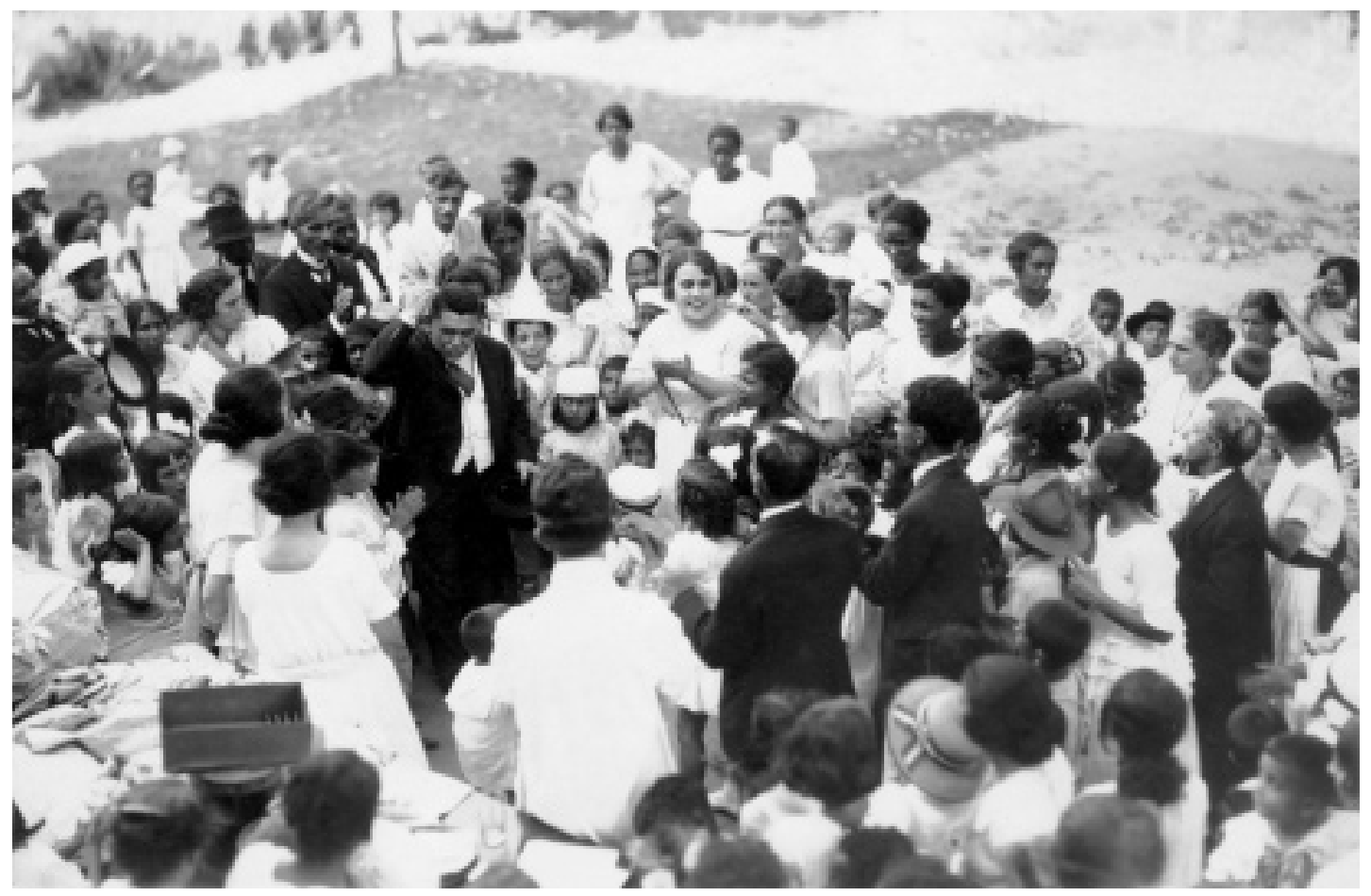

Belisário Penna discursando moradores da região de Pilares. Rio de Janeiro, entre 1918 e 1922.

Arquivo Belisário Penna, Casa de Oswaldo Cruz/Fiocruz. 


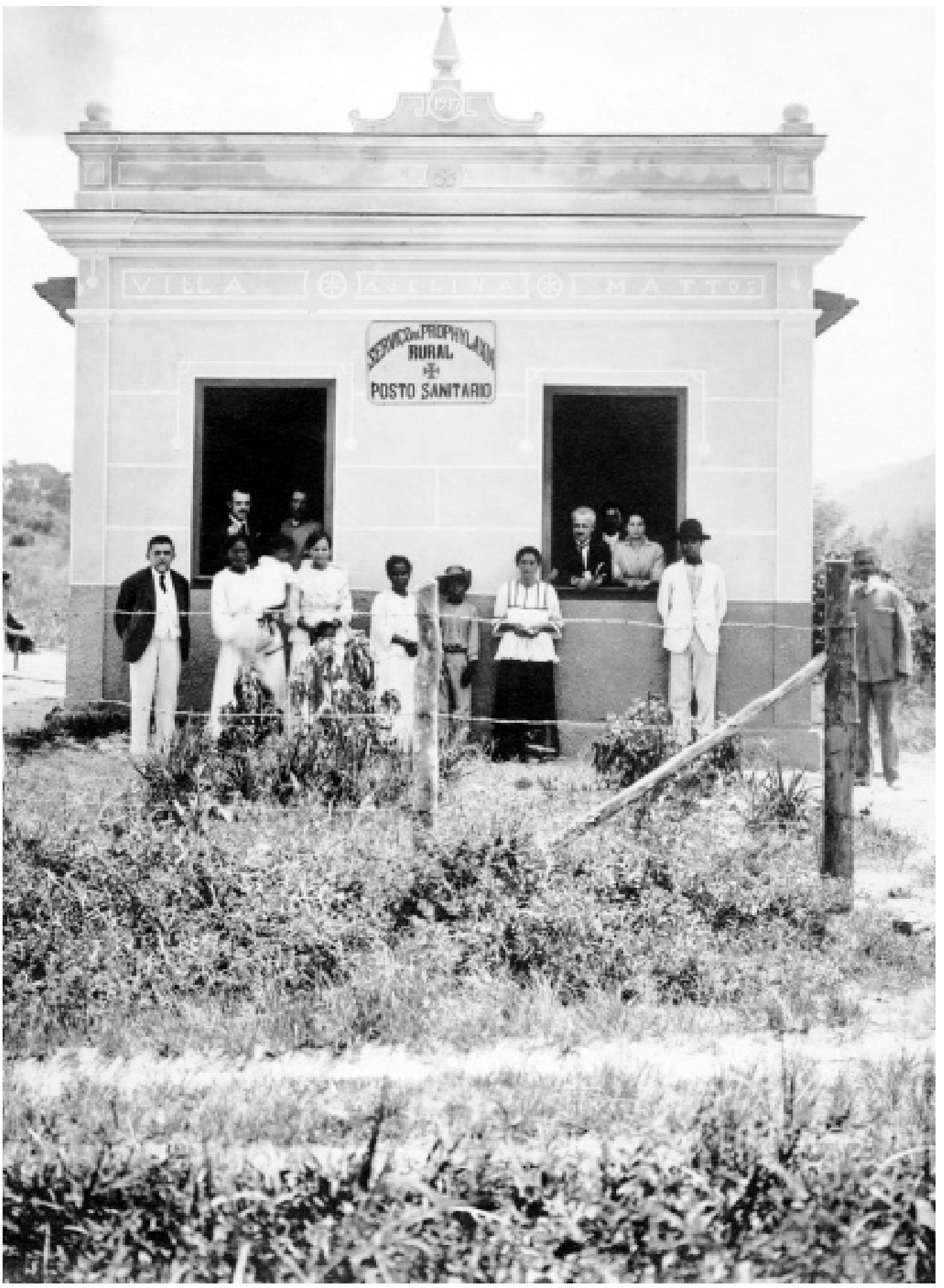

Belisário Penna, primeiro à esquerda, e pacientes do posto de profilaxia rural de Guaratiba. Rio de Janeiro, entre 1918 e 1922. Arquivo Belisário Penna, Casa de Oswaldo Cruz/Fiocruz. 


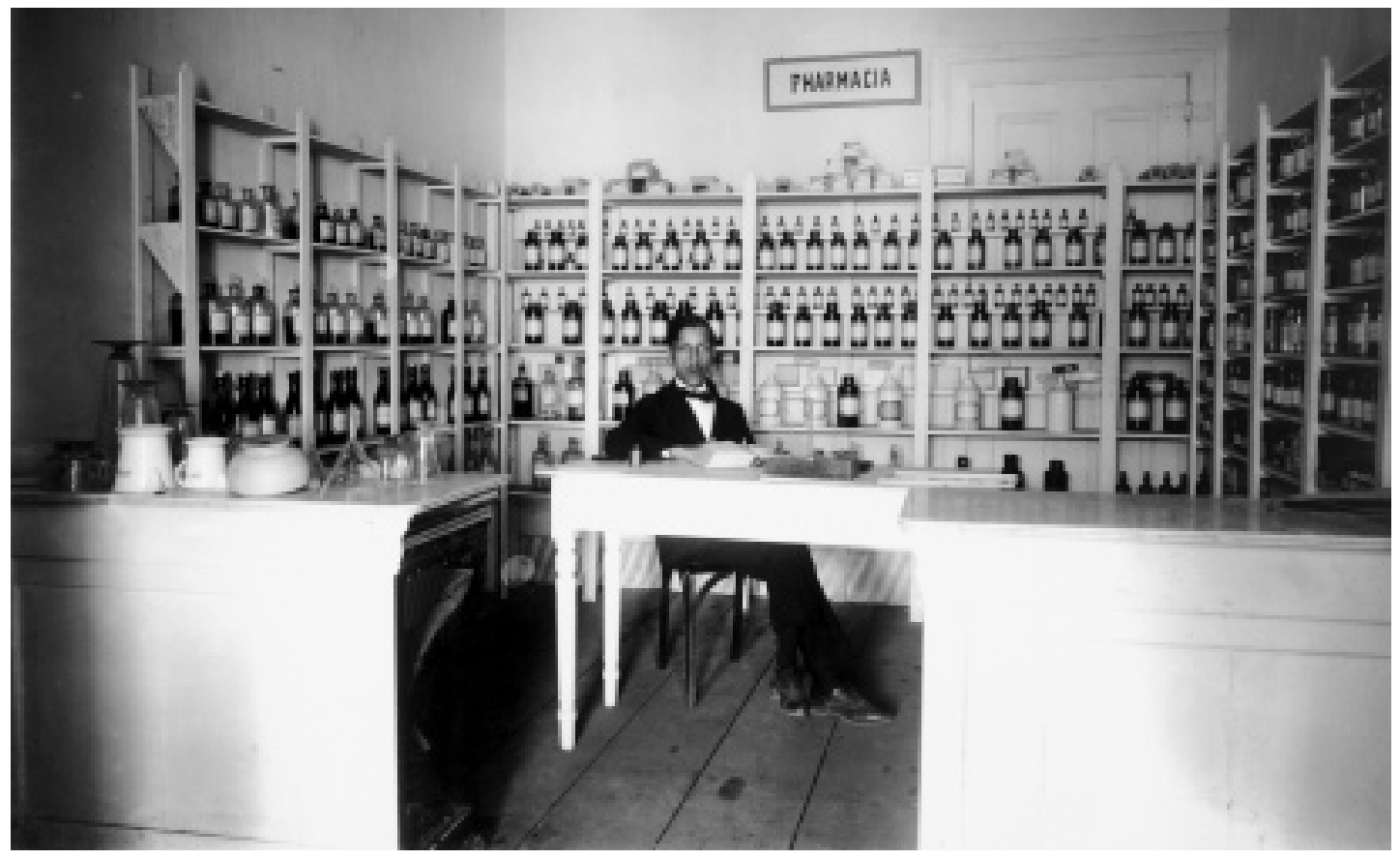

Farmácia do posto de profilaxia rural de Itaguaí. Rio de Janeiro, entre 1918 e 1922. Arquivo Belisário Penna, Casa de Oswaldo Cruz/Fiocruz.

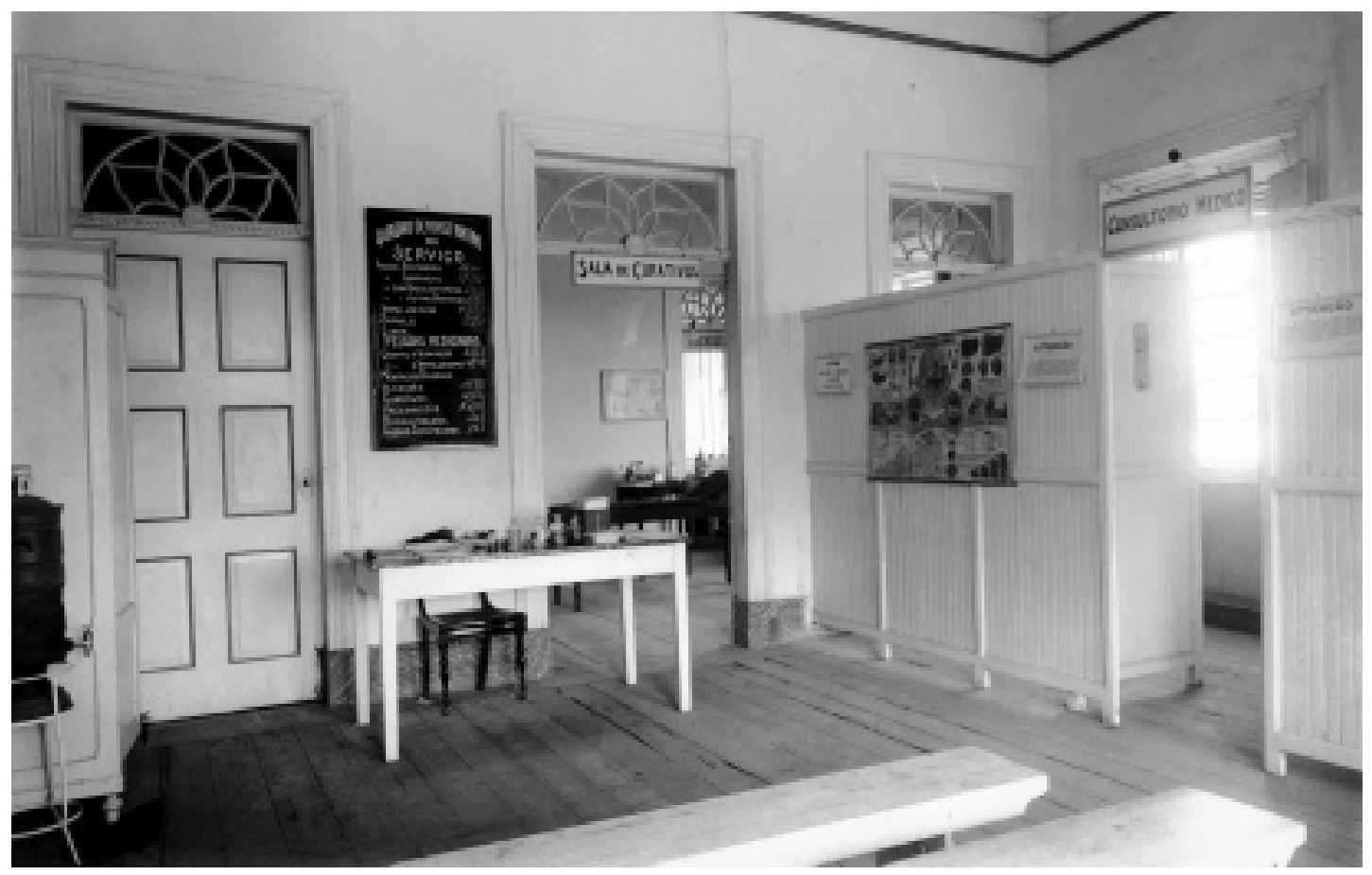

Aspecto do posto de profilaxia rural de Itaguaí. Rio de Janeiro, entre 1918 e 1922.

Arquivo Belisário Penna, Casa de Oswaldo Cruz/Fiocruz. 


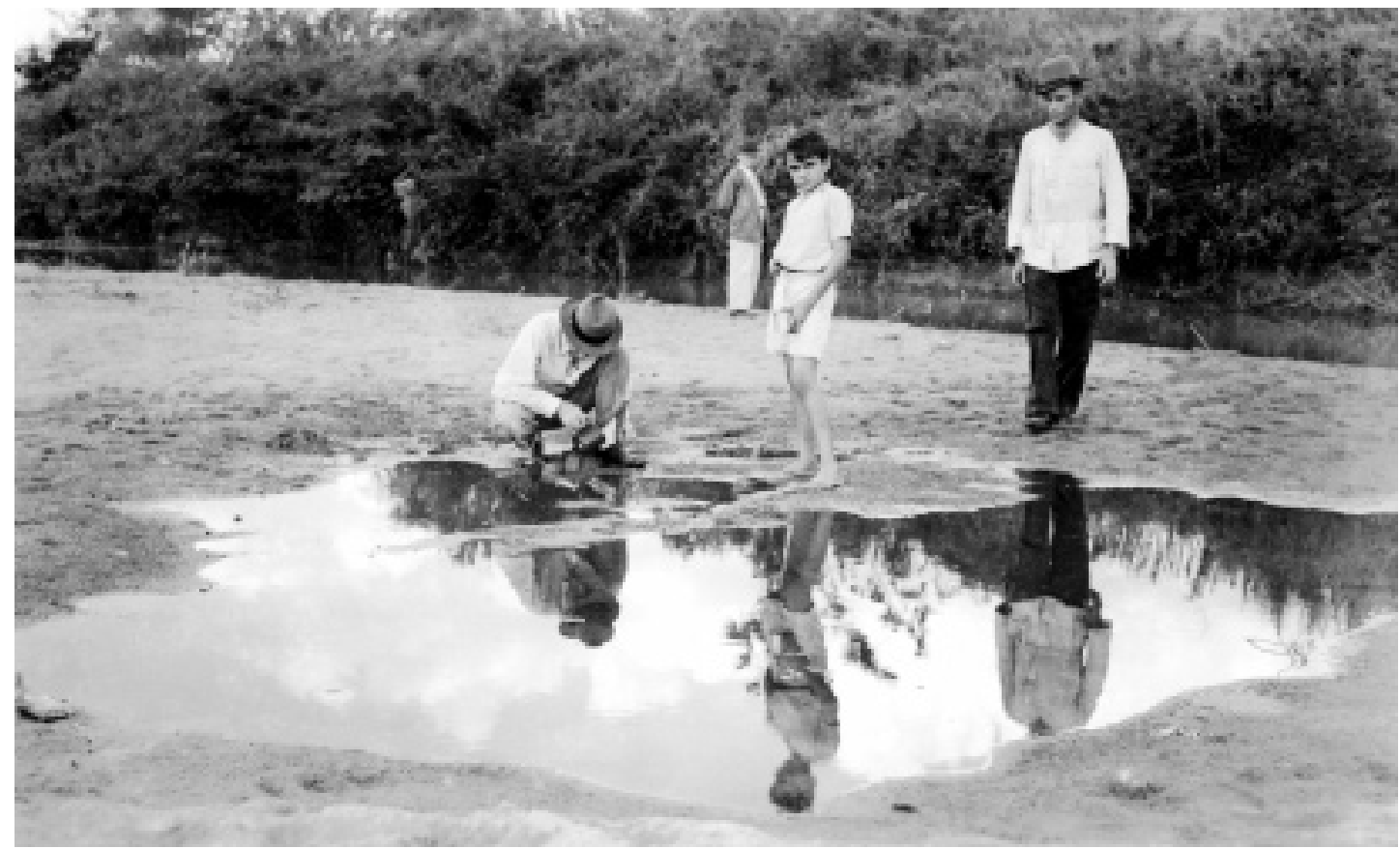

Pesquisa de focos de larvas do Anopheles gambiae no Rio Banabuiú, em Limoeiro. Ceará, novembro de 1938. Arquivo Fundação Rockefeller, Casa de Oswaldo Cruz/Fiocruz.

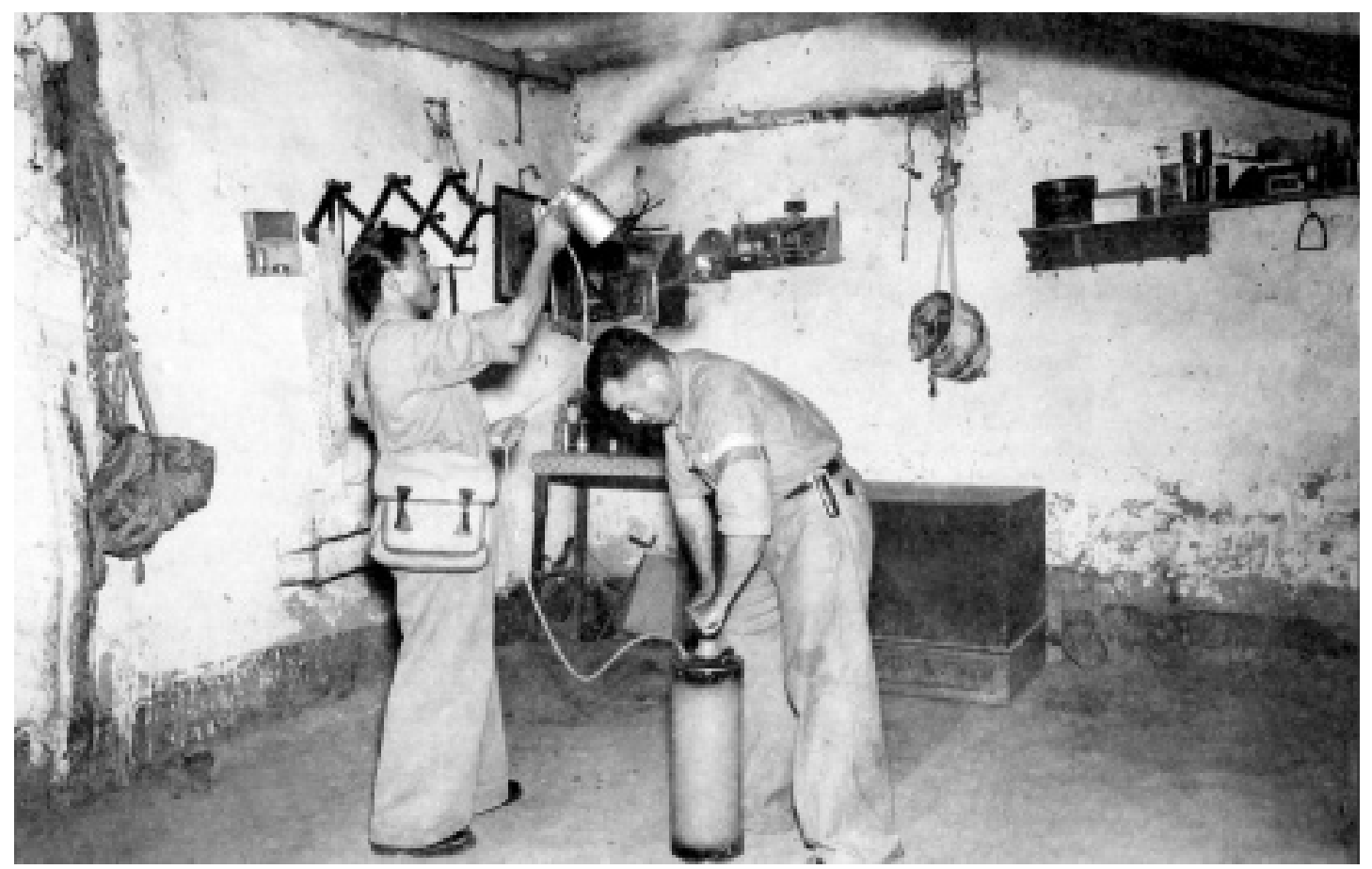

Expurgo domiciliar com compressor De Vilbiss, durante a campanha contra o Anopheles gambiae no nordeste brasileiro. Ceará, 1940. Arquivo Fundação Rockefeller, Casa de Oswaldo Cruz/Fiocruz. 


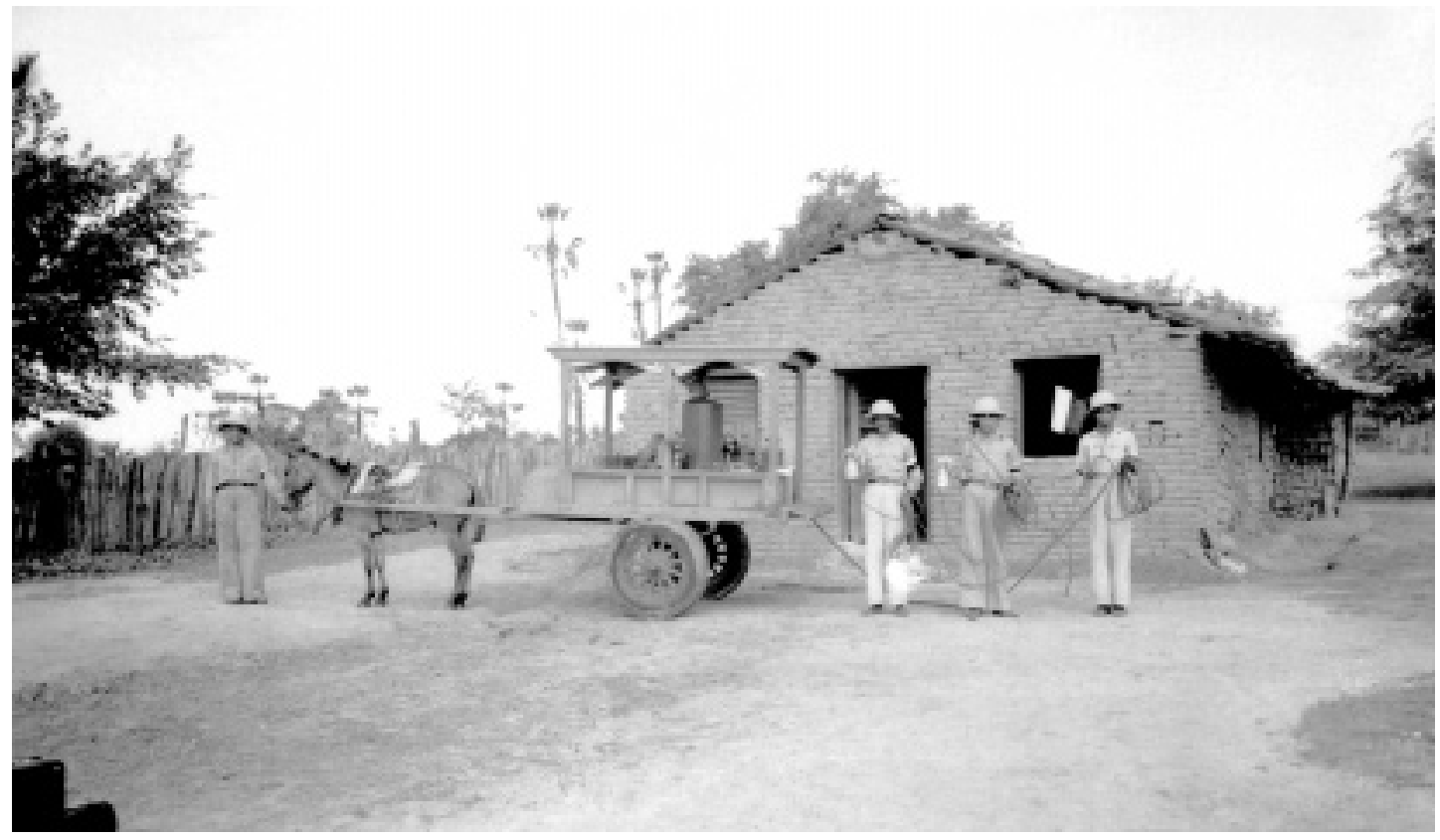

Carroça transportando o compressor De Vilbiss, utilizado para expurgo domiciliar durante a campanha contra o Anopheles gambiae no nordeste brasileiro. Ceará, 1940. Arquivo Fundação Rockefeller, Casa de Oswaldo Cruz/Fiocruz.

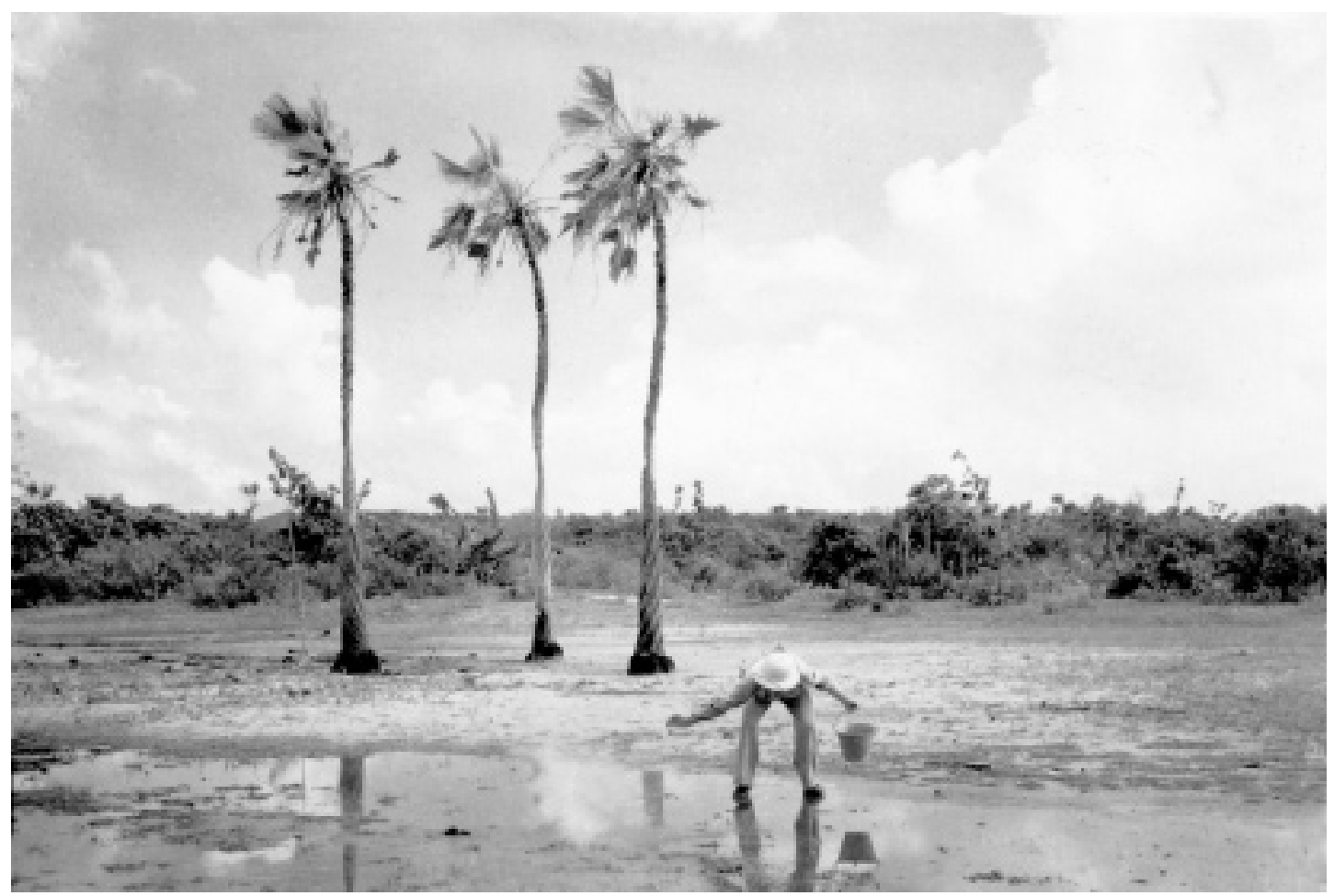

Guarda anti-larvário do Serviço de Malária do Nordeste, espalhando verde-paris em foco de Anopheles gambiae na região de Aracati. Ceará, 1940. Arquivo Fundação Rockefeller, Casa de Oswaldo Cruz/Fiocruz. 


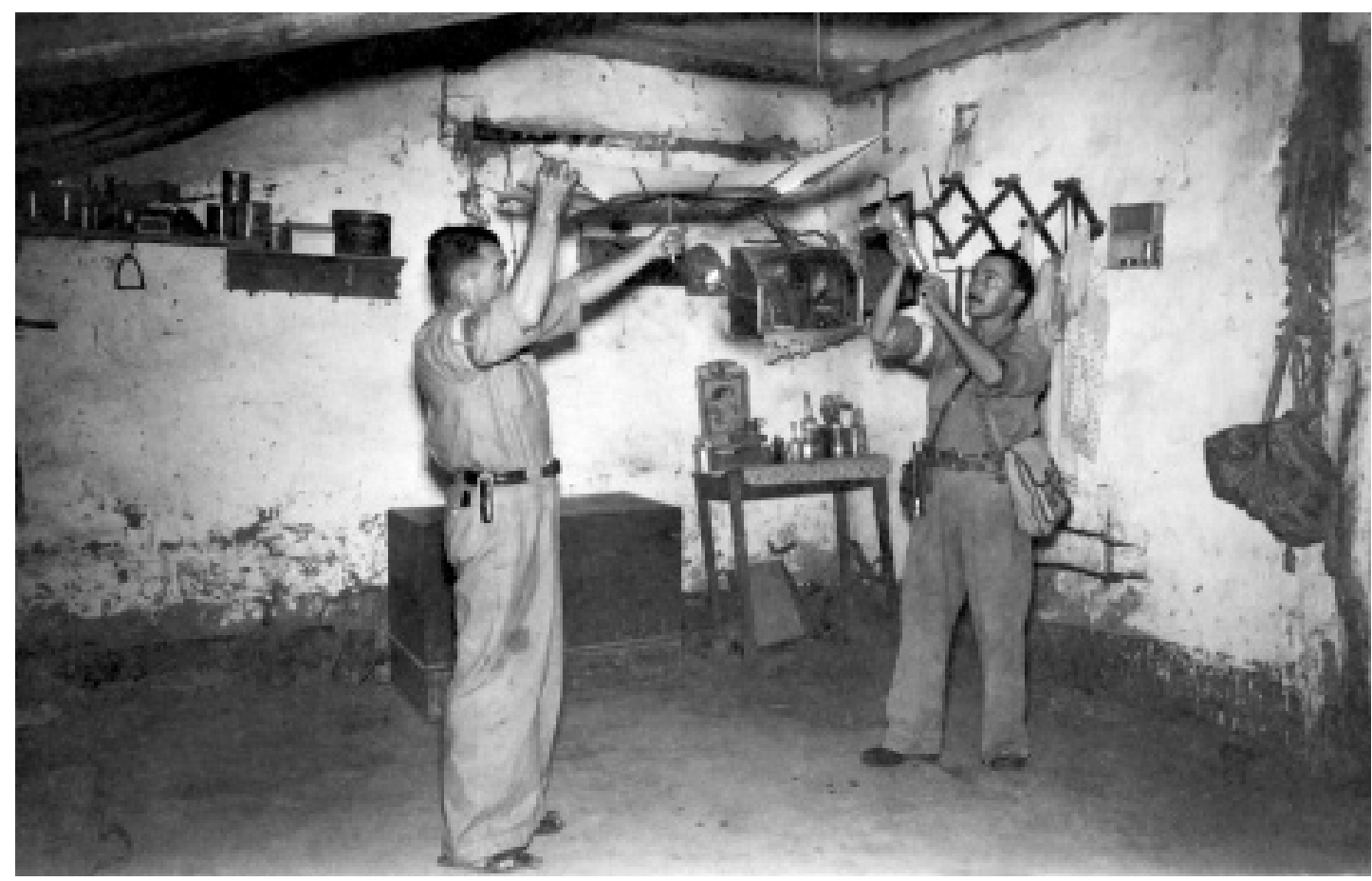

Guardas da turma de captura do Serviço de Malária do Nordeste utilizando o guarda-chuva retangular durante aplicação de inseticida em moradia. Ceará, 1940. Arquivo Fundação Rockefeller, Casa de Oswaldo Cruz/Fiocruz.

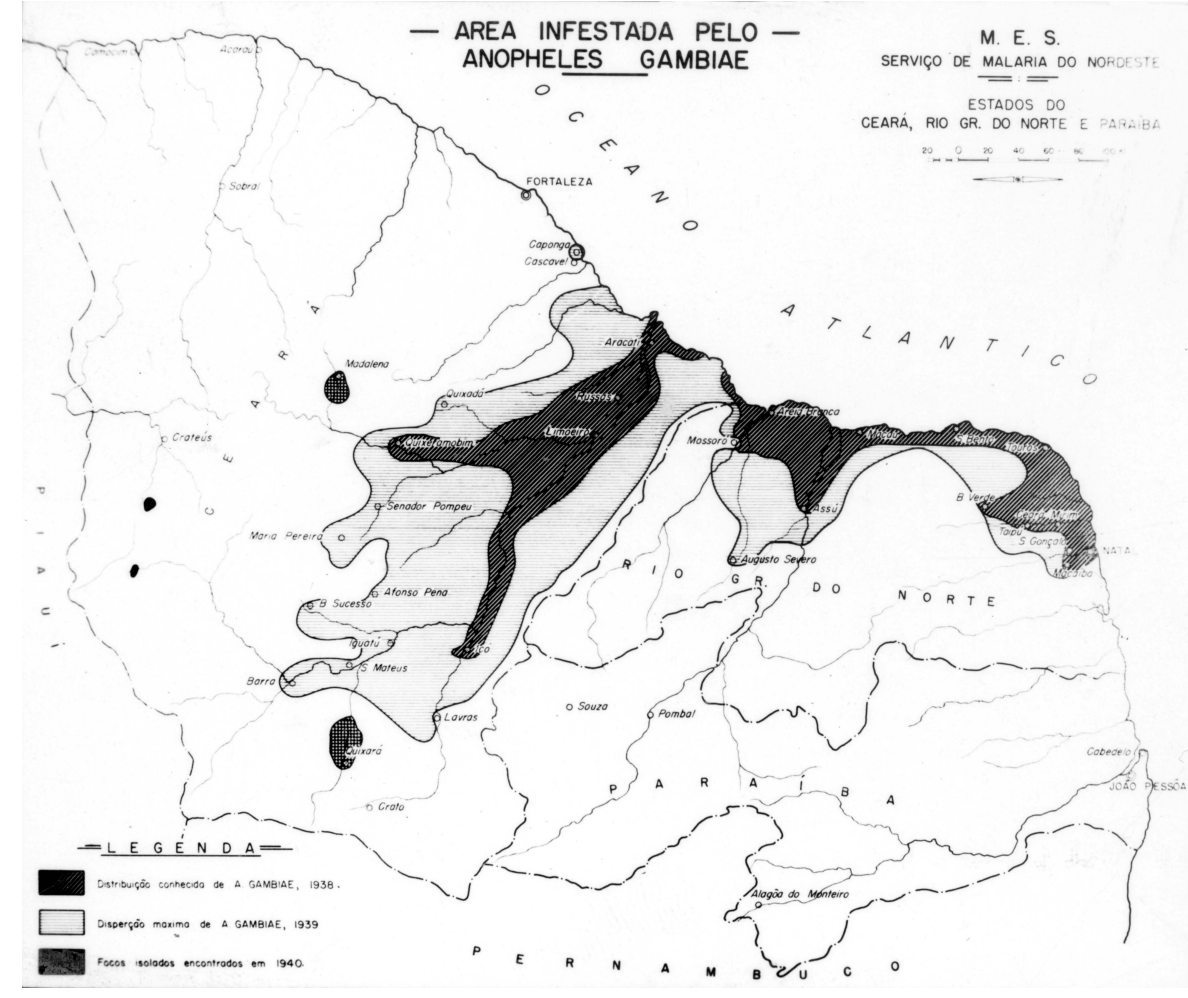

Mapa

representando a área infestada pelo Anopheles gambiae nos estados do Ceará e Rio Grande do Norte, no período de 1938 a 1940. Arquivo Fundação Rockefeller, Casa de Oswaldo Cruz/ Fiocruz. 


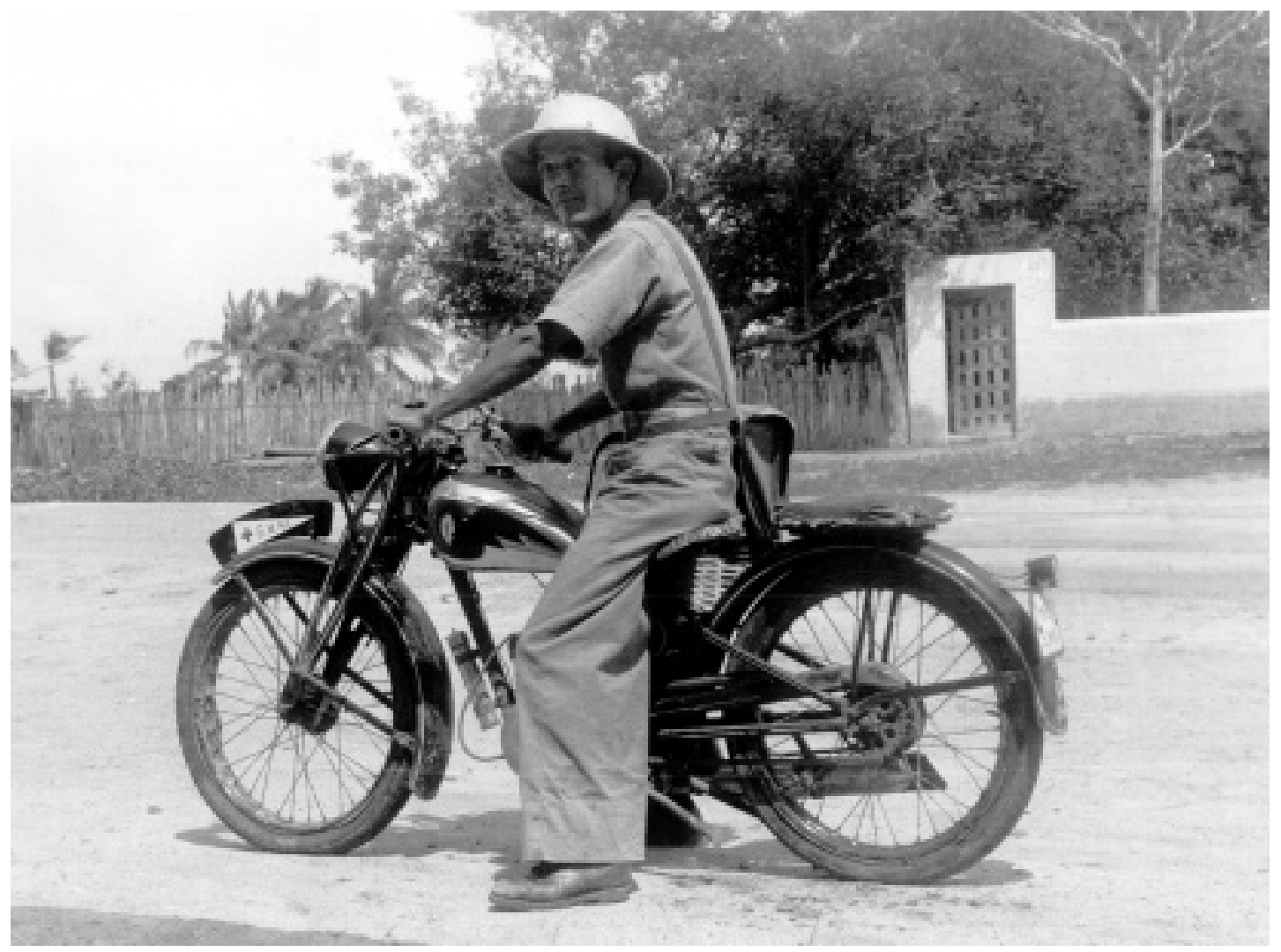

Guarda-medicador do Serviço de Malária do Nordeste. Ceará, 1939.

Arquivo Fundação Rockefeller, Casa de Oswaldo Cruz/Fiocruz.

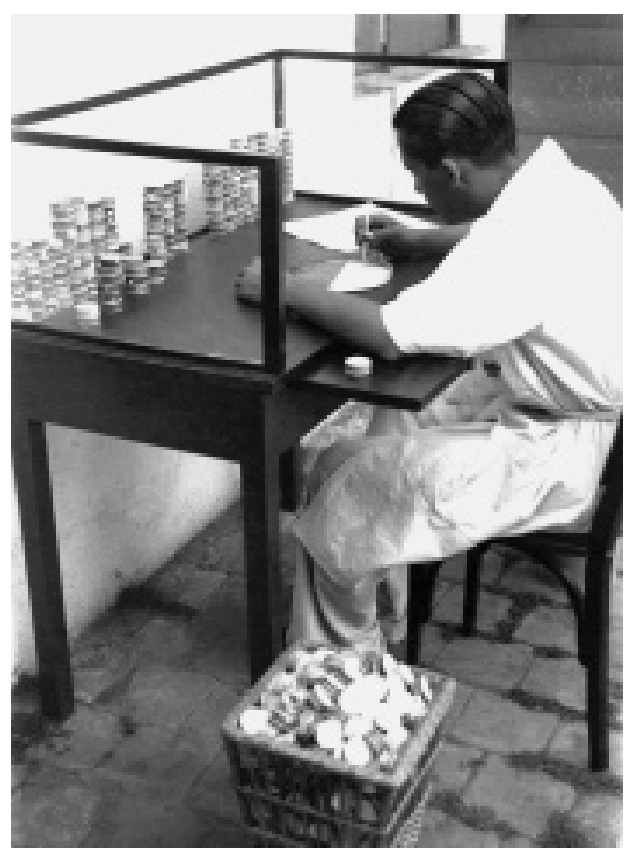

Funcionário do Serviço de Malária do Nordeste realizando o trabalho de classificação de alados no Laboratório de Icó, Ceará. Agosto de 1940. Arquivo Fundação Rockefeller, Casa de Oswaldo Cruz/Fiocruz.

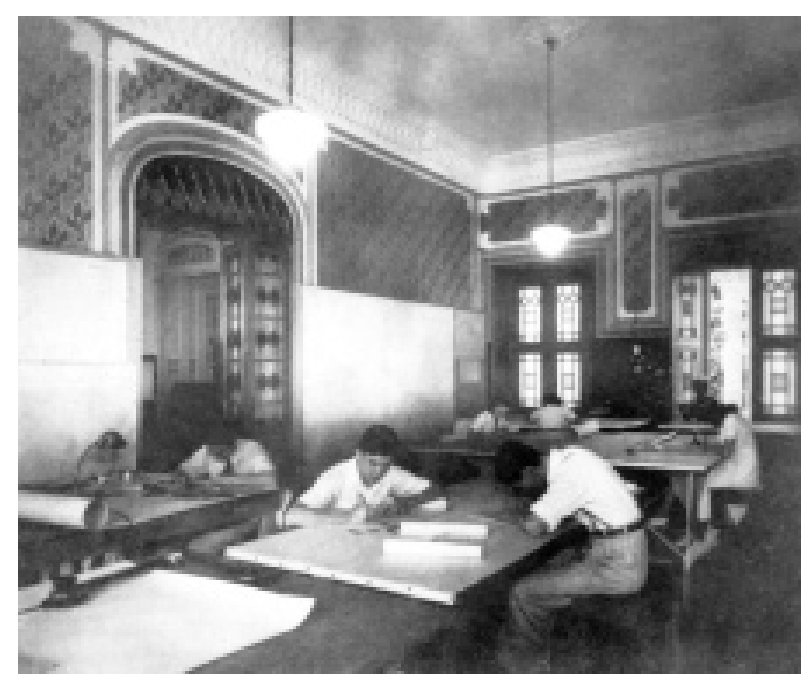

Aspecto da Seção de Cartografia da sede do Serviço de Malária do Nordeste em Fortaleza. Ceará, 1940.

Arquivo Fundação Rockefeller, Casa de Oswaldo Cruz/Fiocruz. 
(2) 4. 5 th -2 . (3) 


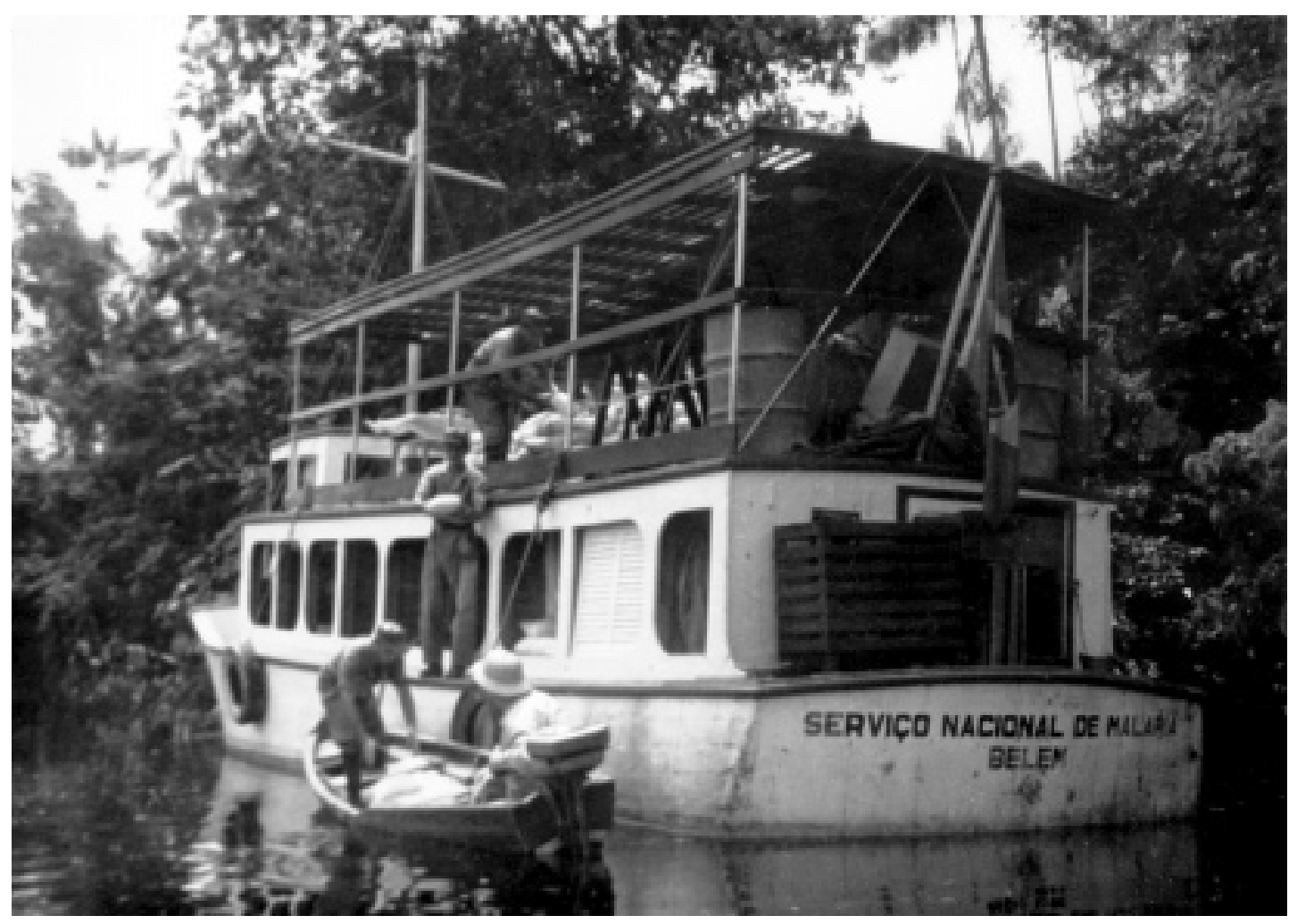

Distribuição do sal cloroquinado em barcos do Serviço Nacional de Malária na Amazônia. Pará, 1952-1953. Arquivo Rostan Soares, Casa de Oswaldo Cruz/Fiocruz.

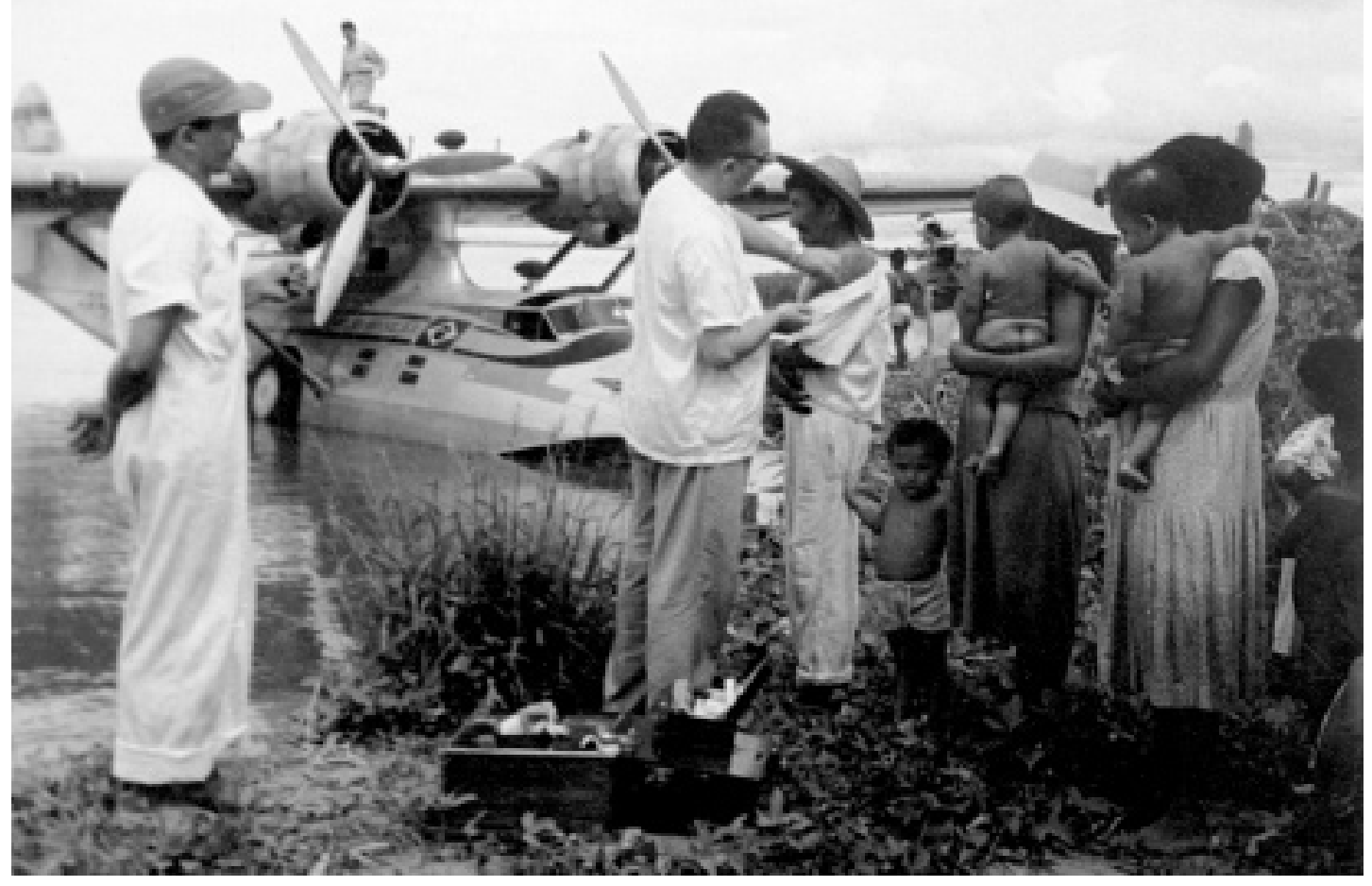

Inquérito epidemiológico realizado pelo Serviço Nacional de Malária, na Amazônia. Pará, 1952-1953.

Arquivo Rostan Soares, Casa de Oswaldo Cruz/Fiocruz. 


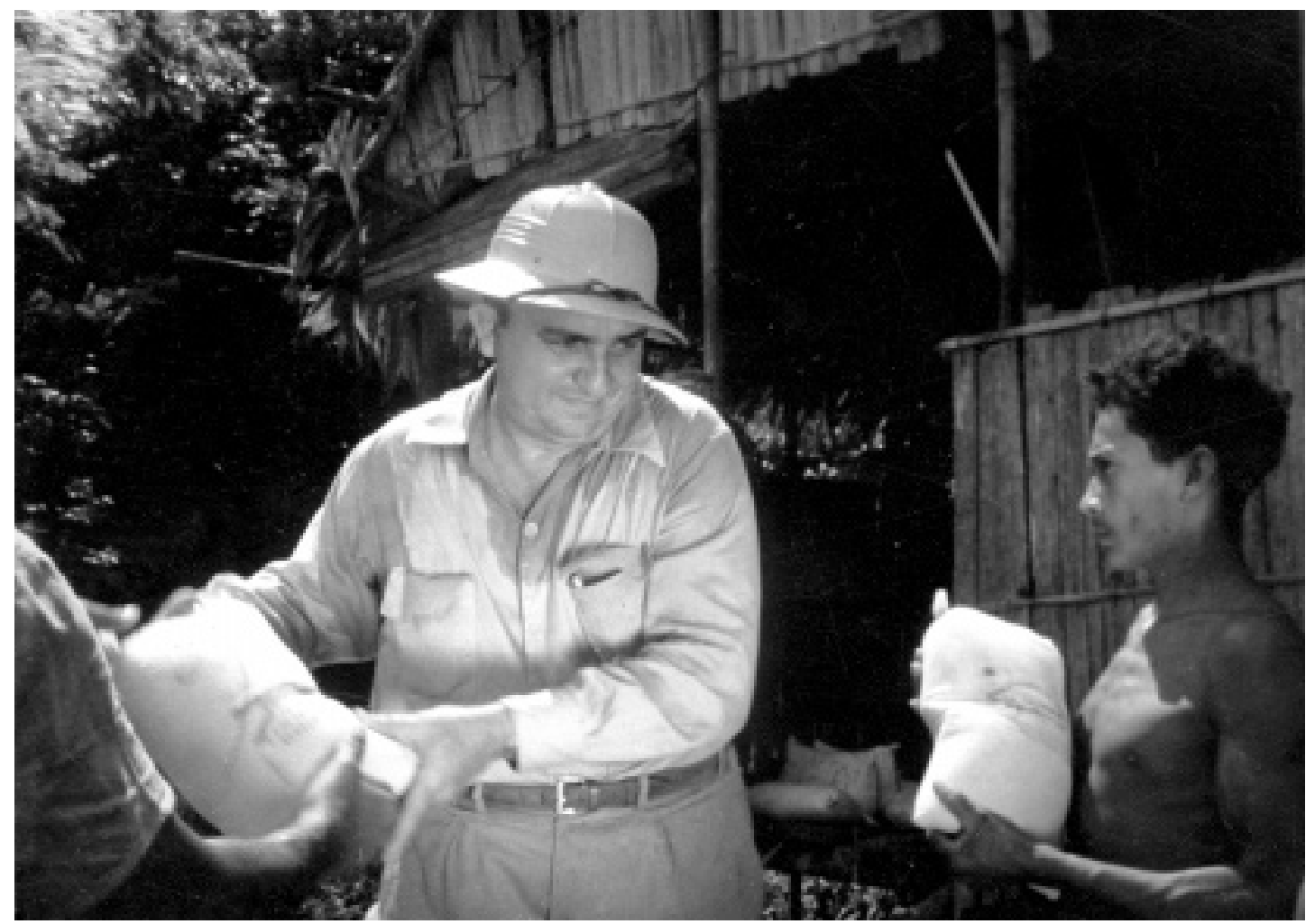

Distribuição do sal cloroquinado à população da Amazônia. 1952-1953.

Arquivo Rostan Soares, Casa de Oswaldo Cruz/Fiocruz.

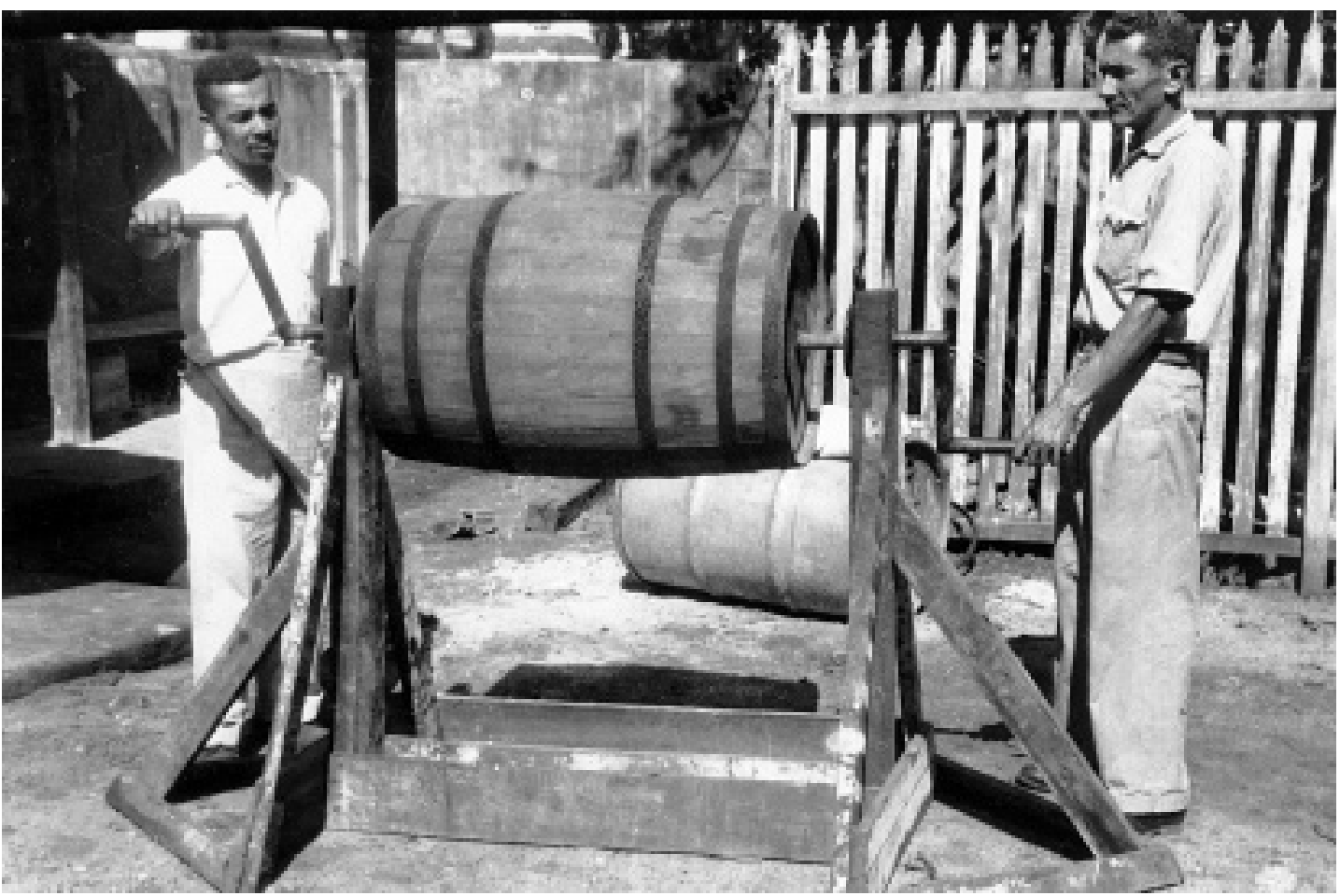

Aspecto da produção de sal cloroquinado na Amazônia, 1953-1953.

Arquivo Rostan Soares, Casa de Oswaldo Cruz/Fiocruz. 


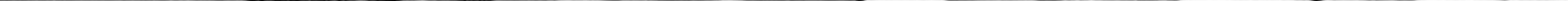


Um outro aspecto a ser mencionado, ainda relacionado aos contextos de produção e utilização dessas imagens, diz respeito às diferentes funções por elas exercidas. Destaca-se o caráter de registro/ testemunho monumental das ações e obras realizadas pelo poder público e pelos diferentes atores políticos, sociais e científicos no combate à malária observado em inúmeras fotografias. Desde o seu surgimento, esse foi um uso social da imagem fotográfica bastante disseminado:

...há que se considerar a fotografia, simultaneamente, como imagem/ documento e como imagem/monumento. No primeiro caso, considera-se a fotografia como índice, como marca de uma materialidade passada, na qual objetos, pessoas, lugares nos informam sobre determinados aspectos desse passado - condições de vida, moda, infra-estrutura urbana ou rural, condições de trabalho etc. No segundo caso, a fotografia é um símbolo, aquilo que, no passado, a sociedade estabeleceu como a única imagem a ser perenizada para o futuro. Sem esquecer jamais que todo documento é monumento, se a fotografia informa, ela também conforma uma determinada visão de mundo (Mauad, 1996, pp. 85-6).

Essa característica é especialmente presente no arquivo de Belisário Penna, no qual as fotografias estão estreitamente relacionadas com a própria trajetória do titular: são imagens que acompanham um personagem politicamente atuante, líder do movimento pelo saneamento do Brasil.

O cuidado no registro das ações empreendidas também se justifica por um outro papel atribuído freqüentemente a essas imagens, qual seja, a de elemento de informação e prova integrante de documentos oficiais tais como relatórios, planos de trabalho, projetos, ou ainda, como ilustração em manuais técnicos normativos e artigos científicos. Revela-se aqui a utilização da fotografia como técnica auxiliar das pesquisas e práticas médicas e científicas sobre a malária. O arquivo da Fundação Rockefeller é exemplar nesse sentido: praticamente todas as atividades relacionadas à campanha contra o gambiae no Nordeste foram detalhadamente fotografadas. A própria forma de apresentação das imagens - coladas em fichas catalográficas contendo os elementos de identificação das mesmas - define sua condição de 'fotografia científica' e sua inserção no processo de investigação, profilaxia e controle da doença. A preocupação em se produzir registros que pudessem ser arquivados, manuseados, interpretados e publicados posteriormente revelam sua importância na produção do conhecimento científico.

Paralelamente à análise dos diferenciados conjuntos de imagens sobre a malária em relação com os contextos históricos específicos e os modelos e estratégias de campanhas utilizados, consideramos ainda necessário confrontá-los com a própria história do meio fotográfico no século XX, com o objetivo de acompanhar, através da observação de 
Este ensaio é uma versão resumida de trabalhos apresentados no XXI Congresso Internacional de História da Ciência realizado na Cidade do México, em julho de 2001, no XXIII International Congress of the Latin American Studies Association, realizado em Washington, D.C., em setembro de 2001 e no VIII Seminário Nacional de História da Ciência e da Tecnologia, realizado no Rio de Janeiro em outubro do mesmo ano. seus elementos técnicos, formais e estéticos, as mudanças de formas e parâmetros de representação assumidos pelas imagens ao longo desse período e que fazem parte da cultura visual de uma determinada época.

Nesse sentido, podemos mencionar, como exemplo, algumas diferenças observadas nos tipos de imagens representativas dos marcos cronológicos dos arquivos aqui tratados: Belisário Penna e Rostan Soares. No primeiro caso, é perfeitamente identificável, nas fotografias das obras de saneamento para o combate à malária, a referência a toda uma tradição estética documental, surgida no final do século XIX, de registros de paisagens, tomadas à distância, nas quais se verifica uma preocupação com uma certa composição do 'quadro fotográfico', ainda bastante influenciada pela pintura acadêmica. Essa influência também se encontra presente nas imagens cujo tema principal é o elemento humano e/ou suas ações — seja o próprio personagem, políticos, médicos, funcionários dos postos de profilaxia rural, doentes etc. - nas quais, via de regra, as pessoas retratadas encontram-se posando e olhando diretamente para a câmera.

Por sua vez, as imagens do arquivo de Rostan Soares apresentam características singulares, típicas de sua época. No caso das fotografias referentes à produção e distribuição do sal cloroquinado na região amazônica, as paisagens estão intermediadas pela presença do elemento humano e de suas ações, que se tornam o assunto principal nesses registros. Existe uma idéia de movimento, de dinâmica, de "captura de um flagrante", mesmo que esse 'instantâneo' possa ter sido previamente arranjado. Este é um dos traços marcantes da concepção de fotorreportagem, que teve suas origens na imprensa alemã do final da década de 1920, foi introduzida no Brasil pela revista O Cruzeiro, nos anos 1940, e só se tornou possível a partir do surgimento e do desenvolvimento das técnicas modernas da fotografia.

As considerações aqui apresentadas objetivam somente indicar algumas das questões suscitadas a partir de um contato preliminar com as imagens dos três arquivos mencionados. Da mesma forma, as fotografias que integram este trabalho, funcionam como síntese e exemplos de um universo de fontes muito mais rico e complexo, constituído de conjuntos orgânicos com suas lógicas próprias de produção e acumulação, e que precisam ser analisados dentro de uma perspectiva de complementaridade com outros tipos de fontes. A malária, que freqüentou permanentemente e com destaque a agenda sanitária brasileira e internacional no século XX, merece estar na agenda de pesquisa dos historiadores e cientistas sociais no século XXI. As novas iniciativas continentais e globais para seu controle e a possibilidade de proteger a saúde dos enormes contingentes populacionais que vivem em áreas de risco podem promover profícua associação entre história e saúde pública no Brasil. 


\section{REFERÊNCIAS BIBLIOGRÁFIAS}

Barata, Rita B.

1998

Benchimol, Jaime L. (coord.) 2001

Benchimol, Jaime L. (coord.)

1990

Braga, José C. de e Paula, Sérgio. G. de 1981

Britto, Nara Azevedo 1995

Campos, André Luiz

Vieira de 2000

Campos, André Luiz Vieira de

nov. 1988

fev. 1999

Casa de Oswaldo Cruz 1991

Chagas, Carlos 1935

Chagas, Carlos 1906-07

Castro Santos, Luíz. A. de 1987

Cueto, Marcos nov. 1998feb. 1999

Deane, Leônidas jan.-mar. 1985

Faria, Lina R. de 1995

Faria, Lina R. de 1994

Fonseca, Cristina M. O. 2000

Fontenelle, José $\mathrm{P}$. 1922

Fraga, Clementino 1926
Malária e seu controle.

São Paulo, Hucitec.

Febre amarela,: a doença e a vacina, uma bistória inacabada. Rio de Janeiro, Editora Fiocruz.

Manguinhos do sonho à vida: a ciência na belle époque. Rio de Janeiro, Casa de Oswaldo Cruz.

Saúde e previdência: estudos de política social. Rio de Janeiro/São Paulo, Cebes/Hucitec.

Oswaldo Cruz: a construção de um mito na ciência brasileira. Rio de Janeiro, Editora Fiocruz.

'Políticas internacionais de saúde na era Vargas: o Serviço Especial de Saúde Pública'. Em Ângela de Castro Gomes (org.), Gustavo Capanema: o ministro e o ministério, Rio de Janeiro, Editora da FGV/USF, pp. 195-220.

'Combatendo nazistas e mosquitos: militares norte-americanos no Nordeste brasileiro (1941-45)'. História, Ciências, Saúde-Manguinhos, vol. 5(3), pp. 603-20.

A Ciência a caminho da Roça - imagens das expedições do Instituto Oswaldo Cruz (1911-1913). Rio de Janeiro, Casa de Oswaldo Cruz/Fundação Oswaldo Cruz.

'Luta contra a malária - conferência proferida no Núcleo Colonial S. Bento, abril 1933'. Em Discursos e conferências. Rio de Janeiro, A Noite, pp. 191-231.

'Prophylaxia do impaludismo'. Brazil-Medico, Rio de Janeiro, vol. 20, n⿳⺈ 33, 41, pp. 315-7, 337-40, 419-22, vol. 21, nº 16, pp. 151-4.

'Power, ideology and public health in Brazil (1889-1930)'.

Tese de doutoramento, Cambrigde, Mass., Harvard University.

'Imágenes de la salud, la enfermedad y el desarrollo: fotografías de la Fundación Rockefeller en Latinoamérica'. História, Ciência, SaúdeManguinhos, vol. 5, no 3, pp. 679-704.

'A malária no Brasil'. Cadernos de Saúde Pública, 1:1, pp. 71-111.

'Os primeiros anos da reforma sanitária no Brasil e a atuação da Fundação Rockefeller (1915-1920). Physis 5(1): 109-129.

'A fase pioneira da reforma sanitária brasileira no Brasil: a atuação da Fundação Rockefeller (1915-1930)'. Rio de Janeiro, Instituto de Medicina Social-UERJ.

'Trabalhando em saúde pública pelo interior do Brasil: lembranças de uma geração de sanitaristas (1930-1970)'. Ciência É Saúde Coletiva, vol. 5, no 2, pp. 393-411.

'Higiene e saúde pública'. Em Dicionário Histórico, Geográfico e Etnográfico do Brasil - Comemorativo do Primeiro Centenário da Independência, Rio de Janeiro, p. 52.

'Saneamento urbano e rural'. Em Livro do Centenário da Câmara dos Deputados, Rio de Janeiro, Imprensa do Brasil, p. 528. 
Frizot, Michel 1998

Gadelha, Paul E. 1995

Gadelha, Paulo E. e Packard, Randall 1994

Gadelha, Paulo E. 1994

Gilman, Sander L. 1995

Gomes, Ângela M. de Castro 1988

Hochman, Gilberto e Mello, Maria Teresa

V. Bandeira de 8-14.7.2001

Hochman, Gilberto 2001

Hochman, Gilberto e. Fonseca, Cristina $\mathrm{O}$. 1999

Hochman, Gilberto 1998

Labra, Maria Eliana 1985

Lacerda, Aline Lopes de set.-dez. 2002

Lacerda, Aline Lopes de 2001

Lima, Nísia Trindade 1999

Lima, Nísia Trindade e

Britto, Nara

1996

Lima, Nísia Trindade e Hochman, Gilberto 1996

Londe, Albert 1987
'Body of evidence: the ethnophotography of difference'. Em A new bistory of photography. Köln, Könemann, pp. 258-71.

História de doenças: ponto de encontros e de dispersões. Tese de doutoramento, Rio de Janeiro, Escola Nacional de Saúde Pública/Fiocruz (mimeo).

'A land filled with mosquitoes: Fred L. Soper, the Rockefeller Foundation and the Anopheles gambiae invasion of Brazil, 1932-1939'. Parassitologia, 36: 197-214

'From forest malaria to bromeliad Malaria: a case-study of scientific controversy and malaria control'. Parassitologia 36, pp. 175-95.

Picturing health and illness: images of identity and difference. Baltimore/Londres, The Johns Hopkins University Press.

A invenção do trabalhismo. Rio de Janeiro, Iuperj/Vértice.

'Campanhas de combate às doenças endêmicas no Brasil do século XX'. Trabalho apresentado no simpósio ciencias, salud y poder en América Latina y Caribe, XXI International Congress of History of Science, México D.F., México, 23p.

'A saúde pública em tempos de Capanema: inovações e continuidades'. Em Helena Bomeny (org.), Constelação Capanema: intelectuais e politicas, Rio de Janeiro, Editora da FGV/USF, pp. 127-51.

'O que há de novo? Políticas de saúde pública e previdência, 1937-45'. Repensando o Estado Novo, D. Pandolfi (org.). Rio de Janeiro, Editora FGV.

A era do saneamento - as bases da política de saúde pública no Brasil. São Paulo, Hucitec/Anpocs.

'O movimento sanitarista dos anos 20: da conexão sanitária internacional à especialidade em saúde pública no Brasil'. Dissertação de mestrado, Rio de Janeiro, Escola Brasileira de Administração Pública/Fundação Getulio Vargas.

'Retratos do Brasil: uma coleção do Rockefeller Archive Center'.

História, Ciências, Saúde - Manguinhos, vol. 9, nº.3, pp. 625-45.

'Em busca de um tempo perdido: fontes visuais para a história da vacina contra a febre amarela.' Em Jaime Larry Benchimol (coord.), Febre amarela: $a$ doença e a vacina, uma história inacabada. Rio de Janeiro, Editora Fiocruz, pp. 443-7.

Um sertão chamado Brasil — intelectuais e interpretações geográficas da identidade nacional. Rio de Janeiro, Revan.

'Salud y nación: propuesta para el saneamento rural. Un estúdio de la Revista Saúde (1918-1919)', Em Marcos Cueto (org.), Salud, Cultura y Sociedad en América Latina: nuevas perspectivas bistóricas, Lima, IEP/OPS, pp. 135-58.

'Condenado pela raça, absolvido pela medicina: o Brasil descoberto pelo movimento sanitarista da Primeira República'. Em Marcos C. Maio e Ricardo V. Santos (orgs.), Raça, ciência e sociedad, Rio de Janeiro, Editora Fiocruz/CCBB, pp. 23-40.

'Sur la photographie médicale'. Em Michel Frizot e Françoise Ducros (orgs.), Du bom usage de la photographie, Paris, Centre National de la Photographie, pp. 85-91.Collection Photo Poche. 
Matos, Marina Ruiz de 2000

Mauad, Ana Maria 1996

Medina, Rosbinda Nunez

1988

Mello, Maria Teresa V. Bandeira de Mello 1998

Moraes, Hélbio

Fernandes 1990

Nájera, José A 2001

Pinotti, Mario abr. 1953

Stepan, Nancy 2001

Stepan, Nancy Leys 1994

Soper, Fred 1977

Soper, Fred e

Wilson, D. B. 1945

Thielen, Eduardo e

Santos, Ricardo A. maio.-ago. 2002

Thielen, Eduardo Vilela 1992

Vasconcellos, Maria

da Penha Costa

1995

Wells, Liz (ed.)

1997

Williams, Steven C. 1994
Malária em São Paulo. Epidemiologia e bistória. Hucitec/Funcraf.

'Através da imagem: fotografia e história — interfaces'.

Tempo, vol. 1:2, pp. 73-98.

'História da campanha de erradicação malária na década de 1950: contribuição para o estudo do modelo campanhista'. Dissertação de mestrado, Rio de Janeiro, Instituto de Medicina Social/Universidade do Estado do Rio de Janeiro. (mimeo.)

Arte e fotografia: o movimento pictorialista no Brasil.

Rio de Janeiro, Funarte.

SUCAM: sua origem, sua história.

Brasília, Ministério da Saúde, 2 vols.

'Malaria control: achievements, problems and strategies'.

Parassitologia 43, pp. 1-89.

'Novo método de controle da malária pelo emprego de medicamentos misturados ao sal de cozinha utilizado na alimentação diária. Revista Brasileira de Medicina, 10(4): 241-6.

Picturing tropical nature.

Ithaca/Nova York, Cornell University Press.

'Portraits of a possible nation: photographing medicine in Brazil'.

Bulletin of the History of Medicine, 68, pp. 136-49.

Ventures in world bealth. The memoirs of Fred Lowe Soper.

Washington, PAHO/WHO, Scientific Publication no 355.

Campanha contra o Anopheles gambiae no Brasil, 1939-42.

Rio de Janeiro, Ministério da Educação e Saúde.

'Belisário Penna: notas fotobiográficas'.

História, Ciências, Saúde - Manguinhos, vol. 9, no 2, pp. 387-404.

Imagens da saúde do Brasil: a fotografia na institucionalização da saúde pública. Dissertação de mestrado, São Paulo, Programa de Pós-Graduação em História, PUC-SP.

Memórias da Saúde Pública: a fotografia como testemunha, São Paulo, Hucitec.

Photography: a critical introduction.

Londres, Routledge.

'Nationalism and public health: the convergence of Rockefeller Foundation technique na Brazilian federal authority during time of yellow fever, 19251930'. Em Marcus Cueto (org.). Missionaires of science: the Rockefeller Foundation and Latin America, Bloomington University Press/Indiana University Press, pp. 23-51. 